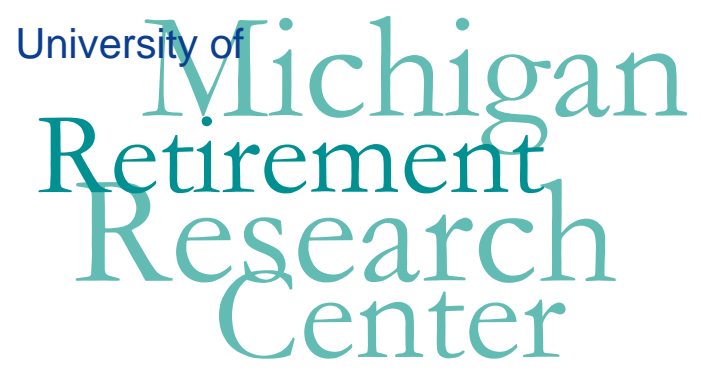

Working Paper WP 2005-098

\title{
Do Individual Accounts Postpone Retirement: Evidence from Chile
}

Estelle James and Alejandra Cox Edwards

\begin{tabular}{|c|c|}
\hline $\mathrm{M}$ & $\mathrm{R}$ \\
\hline $\mathrm{R}$ & $\mathrm{C}$ \\
\hline
\end{tabular}$\quad$ Project \#: UM04-07 


\title{
"Do Individual Accounts Postpone Retirement: Evidence from Chile”
}

\author{
Estelle James \\ Urban Institute
}

Alejandra Cox Edwards

California State University

\author{
April 2005 \\ Michigan Retirement Research Center \\ University of Michigan \\ P.O. Box 1248 \\ Ann Arbor, MI 48104
}

\section{Acknowledgements}

This work was supported by a grant from the Social Security Administration through the Michigan Retirement Research Center (Grant \# 10-P-98358-5). The opinions and conclusions are solely those of the authors and should not be considered as representing the opinions or policy of the Social Security Administration or any agency of the Federal Government.

\section{Regents of the University of Michigan}

David A. Brandon, Ann Arbor; Laurence B. Deitch, Bingham Farms; Olivia P. Maynard, Goodrich; Rebecca McGowan, Ann Arbor; Andrea Fischer Newman, Ann Arbor; Andrew C. Richner, Grosse Pointe Park; S. Martin Taylor, Gross Pointe Farms; Katherine E. White, Ann Arbor; Mary Sue Coleman, ex officio 


\title{
Do Individual Accounts Postpone Retirement: Evidence from Chile
}

\author{
Estelle James \\ Alejandra Cox Edwards
}

\begin{abstract}
Postponing retirement will become increasingly important as a means to increase the labor force, its output and old age security, as populations age. Recent research has focused on incentives stemming from the social security system that influence the worker's decision to retire. Defined benefit systems (both public and private) often contain penalties for postponing access to pensions or continuing to work while receiving a pension. In contrast, the tight link between contributions and accumulations and the actuarial conversion of accumulations into pensions in privately managed defined contribution systems may lead workers to postpone pensions or to continue working after withdrawals begin. The experience of Chile, which implemented its new system in 1982, offers an opportunity to test if the change in incentives has indeed produced the expected change in retirement behavior. Using probit analysis of household survey data from 1960 to 2002, we estimate the impact of the pension reform on the probability of 1 ) becoming a pensioner and 2) dropping out of the labor force, for older workers. We find strong effects of the new system on both propensities, in the aggregate and at the individual level after controlling for individual and macro-economic variables. In particular, restricted access to early pensions and the exemption of pensioners from the pension payroll tax appear to exert a powerful effect on labor force participation rates.
\end{abstract}




\section{Do Individual Accounts Postpone Retirement?: Evidence from Chile}

Postponing retirement will become increasingly important as a means to increase the labor force, its output and old age security, as populations age. We now have evidence that workers respond to incentives stemming from social security systems in making their retirement decisions. Most defined benefit (DB) plans contain incentives that encourage early retirement from the pension system and the labor force (Gruber and Wise 1999 and 2004). In contrast, the tight link between contributions and accumulations and the actuarial conversion of accumulations into pensions in privately managed defined contribution (DC) systems may lead workers to voluntarily postpone retirement. The experience of Chile, which changed from a traditional pay-as-you-go DB to a fully funded DC system in 1981, offers an opportunity to test if the change in incentives has indeed produced the expected changes in behavior. We are not aware of any previous studies addressing this impact of the Chilean reform. ${ }^{\mathrm{i}}$

The old social security system in Chile was very fragmented by occupation and sector, and each sub-system had its own rules. In the largest sub-system, Servicio Seguro Social (SSS), the payroll tax for pensions was 23\%, with another $10 \%$ for other social insurance, bringing the total to 33\%. Workers were eligible for a generous defined benefit after only ten years of contributions. ${ }^{\text {ii }}$ Taking the pension at the first age of eligibility usually maximized the present value of lifetime social security benefits because the "normal age” pension was never decreased in an actuarially fair manner. Continued work in the public sector was not allowed while receiving a pension. Although private sector work was usually allowed, it was penalized. The full contribution rate had to be paid, but the incremental benefit was small and sometimes non-existent. For example, in the SSS

the monthly benefit was $50 \%$ of the base wage after 10 years of service and only $1 \%$ additional for each year thereafter, until a 70\% ceiling was reached after 30 years, at which point the incremental benefit became 0 . In fact, postponed retirement could actually reduce the pension, since the wage base was the average of the last 5 years of work and wages typically peaked between ages 45-50. Incremental benefits were further dampened by the fact that pensions were not automatically indexed for inflation (although inflation at times exceeded $100 \%$ per year). 
In contrast, in the new DC system these work disincentives were removed as payroll taxes were greatly reduced and benefits were linked to contributions on an actuarially fair basis:

(1) Total payroll taxes for pensions were cut to $12.5-13 \%$;

(2) Contributions accumulate in the individual's account, invested in a pension fund (AFP) and earn a market rate of return that exceeded $10 \%$ real per year, on average, for the first two decades of the system;

(3) Upon retirement, the accumulation is turned into a pension on actuarially fair terms, so incremental contributions yield commensurate benefits;

(4) Accumulations and annuities in the new system are expressed in UF, a priceindexed currency, so benefits keep pace with inflation;

(5) At the "normal” retirement age (65 for men, 60 for women) workers can start withdrawing regardless of the amount in their accounts. But those who accumulate enough to purchase a pension that meets a specified threshold may start withdrawing and stop contributing earlier.

(6) Pensioners can continue to work and are exempt from the pension payroll tax. At that point, their net wage rises by as much as $15 \%$ (13/87).

As discussed further below, we would expect the new system to raise the labor force participation rates of older workers, through two channels:

(1) Postponed pensioning. The restrictions on early withdrawal and the actuarial adjustments when withdrawals are postponed should decrease age-specific pension probabilities. This will indirectly increase work propensities, since nonpensioners are more likely to work than pensioners due to liquidity constraints.

(2) Increased work propensities among pensioners. The absence of penalties for continued work, the reduced payroll tax for all contributors and the exemption of pensioners from the pension payroll tax should directly increase labor force participation rates, especially for pensioners.

These effects should be larger for workers who were younger on the date of the reform, therefore more likely to switch to the new system, and should increase over time as a higher proportion of older workers have been in the new system for long enough to take its incentives into account in their life cycle planning. 
Part 1 reviews the literature on determinants of retirement age, in particular on the impact of system characteristics, and outlines in greater detail the work and pension incentives in the new Chilean scheme. Part II describes our data set and aggregate results on the labor supply of older workers and pension probabilities before and after the reform. Part III applies the probit model to estimate the impact of individual, family and system characteristics on the probability of becoming a pensioner and dropping out of the labor force. We focus on changes in the time trend of participation rates of older workers after the reform and changes in the behavior of birth cohorts that reached age 50 after the reform, controlling for other changes in the composition of the work force and the broader economy. The Conclusion summarizes the lessons for other countries.

Our main findings: the labor force participation rates of older men rose substantially after the pension reform. This effect was strongest among pensioners, aged 50-65--a response to their exemption from the pension payroll tax. Simultaneously, the probability of becoming a pensioner prior to the "normal" age of 65 declined-due to tightened eligibility conditions for early retirement. These effects have been accelerating through time and are greater for cohorts that were younger at the date of the reform. This sharply contrasts with the rising pension rates and declining labor force participation rates among pensioners observed before the reform.

\section{What do Theory and Empirical Evidence Suggest about Retirement Choice?}

\section{Studies from other countries}

It is ironic that as people are living longer, they are retiring from the labor force earlier. This will have an increasingly negative impact on labor supply, GDP, and the financial solvency of social security systems in many countries as populations age. During the past decade a large literature has developed to explain the falling labor force participation rate among older men and to suggest policy changes that might reverse this behavior. This research has investigated macroeconomic variables such as higher incomes that lead workers to afford longer periods of retirement, personal characteristics that determine who leaves the labor force early and pension system rules that discourage continued work. We focus on the latter question in this paper. Older workers may be more responsive than prime age workers to system incentives because these incentives 
are often large and older workers have the option of leaving the labor force permanently with pension income rather than adjusting their hours of work marginally while still dependent on wage income.

The benchmark study of this topic is by Gruber, Wise and their colleagues (1999 and 2004). The first volume uses a consistent measure of the incentive to retire early in the defined benefit systems of eleven industrialized countries, and analyzes the relationship between this incentive and the observed labor force participation rates of older men across countries and time. In most countries studied, the increment to social security wealth from an additional year of work is negative long before age 65-it is an implicit social security tax-because the increase in future annual benefits does not compensate for the lost current year of benefits when retirement is postponed. The second volume examines the impact of work incentives at the individual level, using longitudinal micro-data within each country, and two additional measures of work incentives are defined, based on longer-term returns to work. Regressions show that the work disincentives and the responses to them are large; therefore most people retire as soon as they become eligible for a pension; the greater the disincentives facing an individual the less likely he is to postpone retirement; people in different cultural settings have very similar responses; and the longer-term measures of incentives are stronger than the original short-term measure. The simulated effects of policy reforms on retirement choice and labor supply are consistently large.

Several studies using US data emphasize the impact on labor force participation of the income effect stemming from social security wealth and the timing effect stemming from early retirement rules, both of which have changed over the past forty years. Hurd (1990) underscores the peak in hazard rates at age 62 that appeared after the early retirement option was introduced in 1961 (also see Burtless and Moffitt 1986). Hurd also argues that increasing social security benefits in the early 1970's contributed substantially to falling labor force participation rates in the 1980's and 1990's, through an income or wealth effect. However, Burtless (1986), Peracchi and Welch (1992) and Blau (1994) conclude that this impact was quite small. Krueger and Pischke (1992) maintain that the apparent negative impact of social security wealth on labor force participation rates is due to correlated time effects rather than real system effects. They avoid this correlation by analyzing the impact on participation for the "notch generation" that 
retired in the late 1970's and early 1980's. Benefits and social security wealth were suddenly and unexpectedly reduced when double-indexing was eliminated in 1977, yet participation rates continued to fall, suggesting that the downward trend comes from other forces. Gustman and Steinmeyer (1985) simulate the long run response to the 1983 social security reforms and find a positive effect on full time work beyond age 65, mainly due to the increase in the delayed retirement credit—but this is a simulation, not an observation. Anderson, Gustman and Steinmeyer (1999) simulate how behavior might have been different in the US with 1969 rules as compared with 1989 rules and find a modest effect. In general, the estimated effects in these US studies are modest-but this is not surprising in view of the fact that the rule changes have been relatively modest and the US system has long been actuarially fair compared with systems in many other countries.

As for other countries: Borsch-Supan (1998 and 1999) looks at Germany and several other European countries during 1965-2000. He finds differing and changing rates of decline in labor force participation rates of older workers across countries and time, which he attributes largely to varying disincentives coming from their pension systems. Baker and Benjamin (1999) study the impact of the introduction of early retirement options in Canada in the early 1980's. They find that this option had little impact on labor force participation rates-mainly because those who took early retirement would otherwise have had low labor force participation rates anyway and worked only intermittently prior to retirement. Access to early retirement pensions increased their income but changed their behavior minimally as selection rather than incentive effects dominated. In Switzerland (despite a first pillar that nominally does not permit early retirement and a second pillar that is DC, hence rewards continued work) the labor supply of older men has fallen over the past 15 years. Butler, Huguenin and Teppa (2004) attribute this primarily to the maturing of a generous second pillar, which increased the pension wealth of many workers beyond the point they would have chosen voluntarily. Workers spend this wealth on longer periods of leisure in old age. In this way, social security systems can have a negative effect even in actuarially fair systems.

This paper analyzes the actual response to changes in the incentives embodied in Chile's new pension system. Most of the studies mentioned above have had the advantage of longitudinal data, which we do not have. But few studies have had the 
advantage that system incentives have changed so dramatically and that data are available for a long period of time to observe the consequences.

\section{Work and pension incentives in the new Chilean scheme}

Three potentially separable decisions are involved in the choice of retirement age. First is the decision about when to stop contributing to the social security system, second the decision about when to start withdrawing retirement benefits, and third the decision about when to stop work. In principle we could model three separate behavior rules for these three decisions:

1.) Contribute so long as the marginal benefits from incremental contributions exceed the consumption or investment benefits that could be achieved with other uses of the money;

2.) Postpone withdrawal so long as saving is desired and the incremental return to social security wealth (SSW) exceeds the return that could be earned outside the system;

3.) Work so long as the incremental benefits from work (primarily wages and fringe benefits) exceed the marginal utility of leisure.

In traditional DB systems, such as those analyzed by Gruber and Wise (1999 and 2004), these decisions were closely linked by incentives and constraints so a sharp distinction is usually not drawn. Contributions are required so long as the individual works, so the work-contribution decision is joint. Usually the net marginal benefit from incremental contributions becomes negative in early old age, which leads workers to stop working and contributing at the first opportunity--as soon as access to an alternative source of income is established. The rate of return earned on accumulated SSW is usually far less than the market rate of return, so withdrawals in the form of a pension start as soon as eligibility is established. The pension is the alternative income source that enables individuals to stop working and contributing, thereby linking all three decisions together. Sometimes this is reinforced by a requirement that benefits are cut for those who do work or, even more strongly, by a prohibition on work for pensioners. The linkage of these three decisions, together with an early and falling age of eligibility, helps explain the declining labor force participation rates of older men in many countries during the past 3 decades and the lower participation rates in countries with higher implicit tax rates. 
Prior to 1981 Chile also had a traditional pay-as-you DB system that included disincentives to work among older individuals, similar to those found in many European countries today. These include: a high contribution rate that was required for all workers; eligibility conditions that enabled retirement at an early age, beyond which the expected present value of accrued pension wealth would fall; and a failure of incremental benefits to keep up with incremental contributions. In the old system, workers had strong incentives to start their pensions and to stop working and contributing as soon as possible because this maximized the present value of their lifetime net benefits (see endnote 2).

After 1981 a new system based on defined contributions was instituted in Chile, with incentives that were much more pro-work. The new Chilean system delinks these 3 decisions. It sets a threshold replacement rate beyond which workers can become pensioners if they wish. It allows pensioners to work or not work, and if they work to contribute or not contribute, according to their preferences. It also rewards contributions and postponed withdrawals on an actuarially fair basis, using market rates. These forces should decrease the propensity to start the pension-since postponing is no longer penalized--and increase the propensity to work while receiving a pension-since the net wage has been increased by removing the mandatory payroll tax for pensioners and by lower payroll taxes for everyone. Both these effects should increase the labor supply of older workers.

Specifically, in the new system:

(1) Payroll taxes for pensions were cut to $12.5-13 \%$, in contrast to the old rate of $23 \%$ (workers now pay the full contribution while they paid only $7.25 \%$ previously); ${ }^{\text {iii }}$

(2) Contributions accumulate in the individual's account, invested in a pension fund (AFP), and earn a market rate of return that exceeded $10 \%$ real per year, on average, for the first two decades of the system; ${ }^{\text {iv }}$

(3) Upon retirement, the accumulation is turned into a price-indexed pension on actuarially fair terms, so incremental contributions and postponed withdrawals yield commensurate benefits;

(4) Pensioners can continue to work and are exempt from the pension payroll tax. At that point, their net wage rises by as much as 15\% (13/87). (Because of actuarial fairness, only part of the contribution will be considered a tax and the increase in net 
wage will therefore be less than $15 \%$ for most pensioners. Some portion is nevertheless a tax due to time preference and inflexibilities discussed below).

Workers newly entering the labor force were required to join the new system. Older workers were given the option to switch, with recognition bonds (bonos) compensating them for their contributions to the old system. Switching propensities were high and inversely correlated with age. By 1983 77\% of all covered workers had switched to the new system, including most workers under age 50. (Palacios and Whitehouse 1998; Acuna and Iglesias 2001). ${ }^{\mathrm{v}}$

Initially pension withdrawals were allowed at age 65 for men, 60 for women. In the early years few workers were eligible since most workers older than 55 stayed in the old system. $^{\text {vi }}$ Indeed, the new eligibility rules help explain the age-related switching patterns, as male workers in their 50's or early 60's who wished to retire before age 65 could do so only if they stayed in the old system, while younger workers probably had little confidence that the insolvent old system would be able to maintain its retirement age or benefits, hence switched.

In 1987 a new regulation was adopted that allowed workers in the new system to start accessing their retirement funds early, when their accumulations reached a specified threshold. For most of the period analyzed in this study, the threshold was 50\% of their own average wage and $110 \%$ of the minimum pension guarantee (MPG); but in 2004 the government decided to increase this gradually to $70 \%$ and $150 \%$, respectively. ${ }^{\text {vii }}$ This contrasts with the old system, where workers could retire earlier if they had 16 years of contributory service in the main private sector plan or 25 years in the public sector plan. These new pre-conditions for early retirement were more restrictive than in the old system (since it would generally take longer than 16-25 years to attain a 50\% replacement rate on actuarially fair terms). ${ }^{\text {viii }}$ Additionally, in the new system early retirees were eligible only for a reduced MPG, which provided an incentive for low earners to keep their money in the system until age 65. Still, early withdrawal is feasible once the preconditions are met. At that point, keeping money in the account and making further contributions becomes voluntary. Thus, workers have considerable control over when to start withdrawing and when to stop contributing, and their work decision is separable from their pension decision.

\section{Hypotheses about worker retirement behavior}


Propensity to become a pensioner in the new system. We hypothesize that once workers become eligible for pension withdrawal they will continue to keep their money in their social security accounts only if the rate of return earned exceeds their marginal time preference (i.e. they wish to continue saving), also exceeds what they could earn on investments outside the accounts, and this differential is large enough to compensate them for the inflexibilities and non-liquidities that they face in the system. These inflexibilities limit the way money can be invested and the timing of withdrawals. ${ }^{\text {ix }}$ This is a source of disutility, in particular, to individuals who have little savings outside the system and are credit-constrained. We would generally expect such credit-constrained individuals to become pensioners and stop contributing as early as they can, unless they can earn above-market returns in the social security system.

The main source of above-market returns in Chile is the tax system: investment earnings in the accounts are not taxed and additional contributions are tax-deductible, but withdrawals are taxed. These tax incentives are relevant mainly to high earners (who are also least likely to be liquidity-constrained) since low and medium earners pay little if any income tax. Thus, we predict that most workers will still avail themselves of the opportunity to start a pension as soon as possible - the age of withdrawal is mainly determined by eligibility rules. Nevertheless, we expect age of pensioning to be delayed by the new system, in part because of incentives stemming from actuarial adjustments but mainly because of more restrictive eligibility conditions. This delay should come to an end around age 65, at which point everyone is eligible to start withdrawing; ${ }^{\mathrm{x}}$

Impact of pensions on labor supply: the liquidity effect. We expect that pensioners are more likely than nonpensioners to retire from the labor force, as pensioners now have access to an alternative source of income-from their social security wealth. A liquidity constraint has been removed. In that case, the reduced propensity to become a pensioner just predicted should increase the aggregate labor force participation rate of older workers — until age 65.

Impact of payroll tax on work decisions: substitution effects. Both pensioners and nonpensioners should have a substitution effect toward work stemming from the closer link between benefits and contributions. But a much stronger substitution effect applies toward pensioners, who do not have to make any further contributions, in the new system. Some pensioners will continue to contribute voluntarily because this entitles 
them to disability and survivors insurance through a group policy for which they pay about $1 \%$ of wages each year, which is far less than such insurance would cost on an individual basis. Individuals who place a high value on this insurance and who wish to continue saving, will continue contributing. But for the majority, the same factors that led them to start withdrawing will also lead them to stop contributing-they prefer to consume or to save in a more flexible manner. This exemption from the pension payroll tax will increase the net wage of pensioners. ${ }^{\text {xi }}$ The reform should therefore have a much larger impact on labor force participation rates of pensioners than nonpensioners.

Summary of hypotheses. Therefore, we would expect the following impacts on work and pension probabilities:

1. The reform will postpone age of pensioning, at least until age 65, partly because of actuarial adjustments but mainly because of tightened conditions for early retirement.

2. The reform will increase the labor supply of older workers, both because it

a. decreases age-specific pension probabilities, therefore liquid wealth; and

b. increases the net wage, especially among pensioners.

3. Nonpensioners will have higher work propensities than pensioners because of liquidity constraints. But the greatest increase in labor force participation after the reform will occur among pensioners, because of their exemption from the pension payroll tax. (The implication is that actuarial equivalence of contributions and benefits still leaves a substantial tax component).

4. These effects should be greater for individuals who were younger on the date of the reform, hence more likely to be in the new system. The effects should be phased in over time as more workers have time to take its rules into account in their life cycle planning.

The data turn out to be consistent with these predictions.

\section{Data and Aggregate Results}

\section{Data}

The key data source for the analysis is the Universidad de Chile Greater Santiago Area Encuesta de Ocupación, a household survey representative of the capital city and its surrounding metro area, of 2500-3,000 households, that has been collected since 1957, 
with the latest available data from 2002. This survey is collected four times a year to measure the rate of unemployment, but the June survey also contains data on income sources, both labor and non-labor. For all members of the household, we know their gender, schooling, marital status and number children, as well as their current wage, pension and other income. We link our data set to variables that measure the macroeconomic conditions for each year of the survey, such as unemployment or growth rates. The chief advantage of these data is that they allow us to construct synthetic cohorts and follow their employment and retirement trajectories, both before and after the pension reform. To construct these synthetic cohorts we use data on 92,924 males over age 30 who were born after 1900 and were observed some time between 1960 and 2002, focusing on the subset (37\%) who were over age 50 when they were observed.

This data set, however, has several shortcomings. It is not a longitudinal data set. Nor does it give retrospective data on earnings, pension accumulations or age of retirement. ${ }^{\text {xii }}$ We do not know whether the pensions are due to normal old age, early retirement, disability, survivors, minimum pension guarantee or social assistance. (By focusing on men over age 50 we hope to be capturing mainly old age and early retirement rather than other pension types) ${ }^{\text {xiii }}$. We observe the stock of retirees and do not know whether they retired this year or previously, under new or old system rules. For workers and other nonpensioners we do not even know if they are covered by any system and, if so, whether they contributed steadily through their adult lives and are contributing currently. Taking the proportion of men age 70-74 who collect pensions as an ultimate indicator of coverage, this percentage has been $71-75 \%$ since 1981. This suggests that among cohorts born after 1907, which includes all post-reform cohorts and some prereform cohorts, coverage was over $70 \%$, but it was lower previously. ${ }^{\text {xiv }}$

Since individuals who don't belong to any system or have only marginal affiliation are unlikely to be affected by the reform, our inability to remove them from the data set leads to an underestimate of the impact of the reform among those who do belong. By definition all pensioners belong, so this underestimate of labor supply effects is absent among pensioners. But the understatement does apply to nonpensioners, in particular, to very old nonpensioners. This would lead us to expect that our data would show relatively little effect on the propensity to work, after age 65 or 70 . The fact that coverage was lower for very early cohorts also leads us to underestimate the depressing 
impact of the reform on pension probabilities among those who are covered. If we could distinguish affiliates we would find a bigger impact and if coverage rates were to increase in the future the total impact of the reform would be greater than our estimates, for these reasons.

A related measurement error occurs due to the absence of information on whether workers and retirees are new or old system affiliates. Instead, we make inferences about these affiliations based on year of birth or observation. For example, cohorts born before 1931 were likely to be old system affiliates, and those born after 1931 were more likely to become new system affiliates--but the correlation between birth date and affiliation is not $100 \%$. The fact that we do not know the individual's affiliation means that we further underestimate the impact of the reform on new system affiliates, especially in the early years of the reform and regarding workers who were around age 50 in 1981. It also means that we observe a phase-in of the pension reform rather than an immediate full impact, as an increasing proportion of workers approaching old age were new system affiliates as distance from 1981 grew (see Table 1).

Fortunately, all these biases lead us to underestimate reform impacts. Any impact that we find is probably smaller than the actual behavioral effects.

Because of the difficulties in pinpointing who is likely to be affected by the reform, we model the reform in three different ways: 1 ) as a change in time trends of pension rates and labor force participation rates before and after 1987; 2) a change in the behavior of cohorts born after 1931; and 3) year dummies interacted with relevant age groups for each year after 1987. (We use 1987 as the year when change might begin, as most workers who were contemplating retirement shortly after 1981 were likely to stay in the old system and follow through on their plans).

\section{Summary of aggregate data}

As a first step, we look at the aggregate data without controlling for individual or macroeconomic effects. We (1) create synthetic cohorts of individuals born in the same year and follow their labor force participation rates as they age, comparing these aging profiles across pre- and post-reform cohorts; 2) observe labor force participation rates by age group, as these age groups are observed at different points in time before and after the reform; and 3) construct approximate hazard and survival rates curves for the pre- and post- reform groups. 
Differential age-work behavior by cohort. Table 1 shows several groups of birth cohorts, in 5-year groupings, and the age they were in 1981 (the year of the reform) and 2002 (the last year in our sample). The first cohort group, born 1916-25, is our "control group," in the sense that they were so close to retirement (or already retired) in the year of the reform that they are unlikely to have been affected. The second cohort, born 192630, would show only small effects, as they were 51-55 in 1981, their life plans had already been made, and many did not switch to the new system because they planned to retire soon. (This means that most individuals observed in our sample beyond age 70 retired under old system rules). In the next 3 cohort groups we would expect an increasing impact of the reform, as they were more likely to have switched and had more time to plan in accordance with its incentives. The cohort born 1931-35 could have been observed in young-old age (50-64) or old-old age (65 up to 71). Cohorts born between 1936 and 1945 are expected to show larger reform effects, but they would appear only in the young-old age range, due to the cut-off year in our sample. The final cohort, born 1946-50, was in the new system for almost all of its working life and barely entered the young-old category, in their early 50's, when our survey data end.

As expected, the aggregate data show that in prime age all cohorts had very high labor force participation rates, exceeding $95 \%$, and these rates fall after 50 for all cohorts. However, for the cohorts that reached age 50 after the reform (born after 1931), work propensities fall with age at a much slower rate (Table 2 and Figure 1). Consequently, for any given age, labor force participation rates of older men gradually increased for successive cohorts during the post-reform period, in contrast to the pre-reform period when they were decreasing. For example, the participation rate of men age 55-59 was $70 \%$ for the pre-reform cohort born $1921-25$. It then rose to $80 \%$ for the first post-reform cohort born 1931-35 and 88\% for the later post-reform cohort born 1946-50. Among pensioners, participation rates were much lower and the changes more dramatic. For the same age group, they rose from $16 \%$ for the $1921-25$ cohort to $33 \%$ for the $1946-50$ cohort.

At the same time, the probability of becoming a pensioner by age 55-59 was 30\% for the 1921-25 cohort, but fell to 13\% for the 1946-50 cohort (Table 2, Figure 2). Labor force participation rates are much higher for nonpensioners than for pensioners (over 
$90 \%$ until the early 60 's for nonpensioners). Thus, this shift to later age of pensioning accounts for a large part of the observed increase in aggregate work propensities.

Differential behavior by age groups through time. Similarly, we looked at labor force participation rates by age groups observed at different points in time. The work propensity of prime age men has been quite stable, at 95-98\%, before and after the reform. In contrast, labor force participation rates of older men actually declined for about 15 years prior to the reform - a phenomenon that has been observed in many countries - but this decline came to an end in the mid-80's, when a sharp increase began (Table 3 and Figure 3). This contrast between prime age versus older males lends credence to our argument that incentives from the pension system are driving behavior. The post-reform increase in work propensities shows up in the 1980's for the young-old (50-64) but by the 1990's it reaches the old-old (65+) groups. ${ }^{\mathrm{xv}}$

Participation rates are substantially lower among pensioners, but pensioners experienced the strongest positive effects from the reform (Table 3 and Figure 4). Among pensioners age 55-64 the participation rate tripled between 1982 and 2002, whereas among nonpensioners labor force participation rates were relatively stable. As a result, the gap in work propensities of pensioners relative to nonpensioners narrowed-pension decision became a less close predictor of work decision. For example, a 57-year-old nonpensioner was 6.4 times as likely to work as a pensioner in 1982-86, but by 2002 this ratio had narrowed to 2.2 .

We also observe a postponement of pensioning, starting in the mid-80’s. By 2002 pension probabilities for ages 50-60 were at a 40-year low. However pension rates for workers over age 65 were close to their historic highs, indicating that this is an effect of postponement, not reduced coverage (Figure 5). The postponement of pensioning and the increased work propensities of pensioners are both strongly consistent with our predictions of the impact of the reform. They constitute two channels for the large increase in aggregate labor force participation rates already described.

Approximate hazard and survival rates, pre and post-reform. To analyze hazard and survival rates precisely one must know the individual's age of retirement and the group "at risk" each year, which requires excluding those who dropped out previously. A longitudinal data set would allow us to follow this procedure. Unfortunately, our data set is cross-sectional, we do not know the date at which individuals retired from the labor 
market, previous retirees as well as “at risk" workers continue to appear in our sample subsequently, and the number observed at each age changes due to random variations in the sample and mortality, as well as withdrawals from the labor market and start-up of pensions.

To obtain approximate hazard and survival rates we divide our sample into preand post-reform groups and arrange each group according to age 30...99 at which they were observed. The pre-reform group consists of all cohorts born before 1931 while the post-reform groups was born 1931 or later. We treat each group as a synthetic longitudinal set. That is, we assume that the difference between people observed at ages $t$ and $\mathrm{t}-1$ in the cross-sections is the same as the change that would take place in people observed at ages t and t-1 in a cohort. Following Hurd (1990) and others who have used cross-sectional data, we approximate the hazard rate as $\left(\operatorname{lfpr}_{\mathrm{t}-1}-\mathrm{lfpr}_{\mathrm{t}}\right) / \mathrm{lfpr}_{\mathrm{t}-1}$ and the unconditional survival rate as (\#in labor force $_{\mathrm{t}}$ /\# \#bservations $_{\mathrm{t}}$, where lfpr $=$ labor force participation rate and similarly for pension rates. Since this procedure captures "average" pre and post-reform behaviors and ignores time trends that were taking place within each group, it understates the actual changes in behavior that were noted above and are further analyzed in the next section.

As expected, in the young-old age groups the hazard of withdrawing from the labor force is generally higher and survival rates generally lower pre-reform, with peaks of differences occurring at ages 50, 55 and 60 (Figure 6). These were apparently trigger points in the old system since they indicated age of eligibility for various types of retirement. In the new system such trigger points are less significant. But after age 62, the new system begins to exhibit higher hazard rates (this is necessarily so since practically everyone eventually stops working). The early years of postponed retirement add up to a considerable amount of additional working time, as the labor force participation rates for the new system are well above those for the old system until workers reach their late 60's (Figure 7).

Consistent with previous observations, survival rates in the labor force are much higher for nonpensioners (over 90\% through age 60), but the rise in survival rates postreform are concentrated in pensioners, so the two grow closer together. Specifically, survival rates almost double for pensioners, growing by 10-20 percentage points, but only 2-5 percentage points for nonpensioners (Figures 8 and 9). We interpret the higher 
participation rates for nonpensioners as due to their absence of liquid social security wealth. Their smaller response to the reform is evidence that 1) their already high participation rates leaves little space for further increases, 2) many nonpensioners are not

covered by the new or old systems and are therefore unresponsive to system change and 3) a tax component in the payroll tax remains for nonpensioners even though the new system is actuarially fair, while pensioners are exempt so face an increased incentive to work.

At the same time, the hazard of becoming a pensioner falls after the reform for workers in their 50's and early 60's, due to tightened eligibility conditions. Consequently, the survival rate as a nonpensioner is higher post-reform until age 65, at which point all individuals are allowed to start withdrawing their pensions regardless of amounts in the account (Figures 10 and 11). ${ }^{\text {xi }}$ The higher nonpensioner probability contributes to the increased labor force participation among young-old individuals, even though work propensities among nonpensioners changed very little.

\section{Probit Estimation of Retirement and Pension Probabilities}

Do other forces besides the pension reform account for these effects-such as changing characteristics of the labor force or macro changes in the economy? Unemployment rates rose steadily in Chile from the early 1970's to the mid 1980s, which may help account for falling participation rates before the pension reform. The restructuring of the economy that took place during the late 1970's and early 80's led to a period of prolonged growth that might have encouraged labor force participation after the pension reform. At the same time, schooling levels rose sharply; this might increase wage rates, which could increase labor force participation, but could also increase pension eligibility, which might reduce participation among older individuals. To investigate the relative importance of these factors we use probit analysis to estimate retirement and pension probabilities as a function of the social security reform, controlling for individual characteristics and macro-economic year effects. 
Probit analysis predicts the probability of being pensioned or of being out of the labor market for the entire stock of older workers and retirees. The stock of retirees includes people who never worked and those who worked but retired in past years, as well as the new inflow of retirees in the current year. As discussed in the previous section, it includes a mix of people who worked and retired under new and old system rules, as well as people who were not affiliated or only marginally affiliated to any system. Thus, the following results understate any effects of the reform on new system affiliates, although to a lesser extent for younger individuals and as time moves on. Despite this understatement and despite the inclusion of individual characteristics and macro-economic variables, we find a strong impact of the reform on the pension age and labor force participation of older workers.

\section{Variables}

Our dependent variables are the pension probability $\left(\right.$ PENPROB $\left._{\mathrm{i}}\right)$ and the labor force participation rate $\left(\mathrm{LFPR}_{\mathrm{i}}\right)$, which we model as a function of individual characteristics $\mathrm{X}_{\mathrm{i}}$, time-related macro-economic characteristics $\left(\mathrm{E}_{\mathrm{t}}\right)$ and three alternative indicators of reform (R) defined below. Because we are focusing on older workers, whose behavior and response to variables may differ from that of younger workers, most coefficients are allowed to vary between individuals under and over age 50 and in some cases for individuals over age 65.

$$
\begin{aligned}
& \operatorname{LFPR}_{\mathrm{i}}=\mathrm{LF}\left(\mathrm{X}_{\mathrm{i}}, \mathrm{E}_{\mathrm{t}}, \mathrm{R}\right) \\
& \operatorname{PENPROB}_{\mathrm{i}}=\operatorname{PEN}\left(\mathrm{X}_{\mathrm{i}}, \mathrm{E}_{\mathrm{t}}, \mathrm{R}\right)
\end{aligned}
$$

See Table 4 for a summary of the right hand side variables.

Individual characteristics included in the reduced form analysis are:

age of individual (continuous variable for workers age 50 and over, with the coefficient additionally allowed to vary continuously for age 65 and over). Pension and participation probabilities are very stable in prime age. Older age (over age 50) is expected to increase pension probability due to greater likelihood that eligibility requirements will be met, and to decrease labor force participation rates, due to greater probability of being pensioned (hence having an alternative income source) and lower productivity. Therefore we start the continuous age variable with age $<=50=0,51=1$, etc. We also interact dummies indicating those over age 50 or 65 with some of the variables mentioned below. We refer to ages 50-64 as the young-old and 65+ as the old-old. (65 is 
the "normal" pension age at which point everyone is eligible to start withdrawing money regardless of size of accumulation, which should increase pension probabilities and decrease labor force participation). Unfortunately, our sample has relatively few old-old affiliates of the new system, and it is difficult to separate them from the old-old who are affiliated to the old system or unaffiliated with any formal system.

education (dummies for $<6$ years and $>12$ years): This is used as a proxy for permanent income and wealth. Low earners (with low education) will find it more difficult to meet the pre-conditions for early withdrawal of money from their accounts, so we expect them to have a relatively low probability of pensioning at young-old age. The illiquidity of their social security wealth and the absence of non-social security wealth should lead workers with low education to be credit-constrained and to stay in the labor force up to age 65. In contrast, the non-pension wealth of those with high education and their easier access to a pension should lead them to retire from the labor force early due to a liquid wealth effect. But this effect is counteracted by their higher wage rates and, after the reform, by the exemption of pensioners from the pension payroll tax-both inducing substitution effects in favor of participation. On balance, we expect that individuals with high education are more likely to become early pensioners and the reform should have a positive impact on their work propensities as pensioners.

real household income minus the person's own wage and pension, per capita (we transform the nominal value pesos into constant values using the consumer price index): Larger incomes from other sources may raise the individual's tax bracket, hence decrease the probability of early pensioning; but it enables the choice of greater leisure financed by other sources, hence it may increase the probability of retirement from the labor market.

marital status and number children under age 18: married men, especially those with children, may continue working later because of larger family consumption demands. They may also pension later because (1) they are required to purchase a joint pension which reduces the amount by about $15 \%$ and therefore makes it more difficult for them to meet the eligibility conditions for early withdrawal; and (2) the expected value to them of disability and survivors insurance is greater than the premium, because of community rating. ${ }^{\text {xvi }}$

difference between own age and age of spouse: a younger wife may require a more extended period of wage income. Additionally, if she works, the husband might 
postpone his own retirement to coincide with her's (Coile 2003, Butler, Huguenin and Teppa 2004).

macroeconomic conditions. A leading counter-explanation for changes in observed behavior during the 1980's and 1990's would be changes in macro-economic conditions in Chile, which were large, during 1960-2002. The country went through a period of economic chaos and hyper-inflation during the early 1970's, high unemployment during the late 1970's, its financial system went through a major restructuring in the early ' 80 's, and it enjoyed a period of prolonged growth that included a compete business cycle from the mid-80's through 2002. The existence of a full cycle is important as it reduces the correlation between the phase-in of the reform and economic growth, and allows us to separate out these effects. We control for these macro-economic changes using rate of unemployment, real annual GDP growth and the Hodrick-Prescott filter for GDP growth as alternative variables. ${ }^{\text {xviii }}$ We expect pension probabilities to rise and labor market participation to fall during downturns in the economy, due to the discouraged worker effect, the greater difficulty older workers may experience in obtaining new jobs when laid off from their existing jobs, and the greater ease of meeting early retirement pre-conditions when periods with 0 wages are averaged into the ownwage base.

Pension status and amount. Pension status and amount play an important role in this analysis. In the old system pension eligibility created large incentives to collect the pension and stop work simultaneously, at an early age. In the new system we expect that most workers will also start their pension as soon as possible, but this is likely to occur later because of more restrictive early withdrawal provisions. Our probit for the probability of pensioning mainly informs us of the characteristics that determine eligibility. Pension status and pension amount then enter into the labor force participation equation as exogenous variables, and we expect them to have negative signs due to the liquid wealth effect. But we expect this sign to be less negative in the new system than in the old, because of the substitution effect stemming from the exemption of pensioners from the pension payroll tax and the absence of other penalties for work.

Rising benefits have been given as one explanation for falling participation rates in the US (see earlier discussion). In Chile, real pension amounts plummeted during the early 1970’s due to hyper-inflation without automatic indexation. But they recovered 
steadily during the late 1970's and more irregularly during the 1980's and 1990's. Cohorts that were born later got larger real pensions. The rise in pension amounts might have been expected to decrease labor force participation rates during the post-reform period. In that case, rising participation rates in the aggregate would be even more surprising. ${ }^{\text {xix }}$

Reform indicators. Our main focus is the impact of the pension reform on pension probabilities and labor force participation rates. We measure reform in three alternative ways, because of the difficulties discussed above in identifying which individuals are covered by the new versus the old systems (versus no system at all). In each case, we interact the indicators with pension status to test our hypothesis that the change in work incentives was greatest among pensioners.

1) change in time trends. In some specifications we include a time trend over the entire period 1960-2002 (time=year-1960). The impact of the reform is captured simply by a change in this time trend starting in 1987 (time87=year-1986). To focus in on older workers, we interact the time trend with dummies for those over age 50 and 65, respectively. We use 1987 as the first year when the trend might change, because at the time of reform (1981-82) workers in their 50's who planned to retire prior to 1987 would have not been able to do so if they switched to the new system. Since the switch was voluntary, workers who planned to retire early would simply have stayed in the old system and their behavior would not have been affected. But most younger workers switched given their lack of confidence in the sustainability of the old system and we expect them to respond to the incentives of the new system.

In particular, as new system affiliates gradually comprised an increasing proportion of young-old individuals, we expect that fewer workers to pension early and more to continue working later. Therefore, the time trend in pension probabilities should fall and in participation rates should rise, for individuals over age 50. We expect pension probabilities to revert to the original time trend for individuals over age 65, at which point everyone is eligible to start withdrawing from their accounts. We also expect a weaker and possibly non-existent effect on labor force participation for individuals over 65 for several reasons - the sample size of new system affiliates is small, among pensioners a higher proportion are likely to be old system affiliates, among nonpensioners a higher proportion are likely to be outside any system, and some new 
system affiliates in this older age category are close to the MPG, which would reduce their incentive to work.

2) Changes in cohort trends. One problem with using time trends is that some older workers observed after 1987 had retired many years before, under the old systemwe wish to exclude these individuals from the reform group but are unable to identify them directly. Another problem is the correlation between time trend and the unemployment rate between 1960 and 1987. Although we control for unemployment, it is possible that this correlation may have led to an overstatement of the negative impact of the system pre-reform and an overstatement of the reversal post-reform. ${ }^{\mathrm{xx}}$ To avoid these problems we organize the data by birth cohort, and compare the behavior of cohorts that were born before and after 1931. Workers born in 1931 or after were younger than 50 on the date of the reform, therefore, they were more likely to switch. Cohorts (coh) are designated continuously by their years of birth, starting in 1900 (if born $<=1916$, coh=0, if born>1916, coh=year of birth-1916). In this case, we model the impact of reform as a change in the coefficient for cohorts born in 1931 and thereafter (if born $<=1930$, coh31=0, if born $>1930$, coh31=year of birth-1930). Again, we interact cohort with dummies for individuals over age 50 and 65. For the reasons given above, we expect the cohort trend in pension probabilities to fall and in participation rates to rise, especially for coh $31 * \mathrm{~d} 50 .{ }^{\mathrm{xxi}}$ For all the reasons given above, we expect a weaker and possibly nonexistent effect on coh31*d65. We also expect the reform effect on older workers per cohort year to be smaller than that per calendar year, because we are spreading the total effect over 22 cohort years (born 1931-52) but only 16 calendar years (observed 19872002).

3) Year-age dummies. Our third approach to identifying the post-reform group is to use a dummy for every year starting in 1987, interacted with the relevant age group of older individuals for that year. In 1987 age group 50-60 could have had pension and participation probabilities affected by the reform, for 1988 this group expanded to ages 50-61, and so on to ages 50-75 in 2002. In contrast to the time trend indicator, this approach allows the reform impact through time to be non-linear and it excludes age groups that are likely old system affiliates. It also allows us to include later cohorts as time moves on. We expect these dummies to have a negative impact on pension probabilities and a positive impact on work propensities. These effects should become 
stronger over time as cohorts that were younger at the time of the reform enter old age and as relevant sample size of pensioners grows.

\section{Results--pension probabilities}

We expect reform to have a positive effect on labor supply from two sources: a decreased probability of being pensioned and an increased work propensity for pensioners. We first look at the factors that influence the probability of receiving a pension. We focus on the population $50+$ because pension income at younger ages is typically driven by disability, on which we do not have information in this survey. The probit estimates are reported in Table 5. We show two specifications-in which reform is captured by time trends and cohort trends, respectively. While the explanatory power is small over-all, most of the variables have the expected effects in both equations.

Not surprisingly, pension probabilities increase substantially with age-by about 2.7 percentage points per age-year after 50, but slowing down after 65, by which point the majority of eligible workers have retired. Pension probabilities are lower for less educated older workers (who are less likely to be in the pension system and to be eligible for early pensioning). As the labor force became more educated over the past 25 years, we would therefore expect pension rates to rise, whereas in reality they fell, leaving a larger gap to be explained. Workers with children and with younger wives are less likely to pension (but, surprisingly, the presence of a spouse increases pension probabilities, perhaps because married workers are more likely to have steady labor market attachment with membership in the social security system). Pension probabilities rise during periods of unemployment-a 1\% increase in unemployment rate increases pension rates by .2-.4 percentage points. Thus, the increase in unemployment rates during the 1970's would be expected to increase pension rates by 3-4 percentage points. The unemployment effect is somewhat smaller in the equation with time trends as compared with cohort trends, since, as noted above, time trends may have picked up some of the unemployment effect in the

pre-reform period. Other macro indicators were not significant and are omitted from the final equations.

Most important for our purposes, in both cases reform leads to a significant reduction in the probability of pension, after controlling for other variables. The incremental reduction per year is larger in the equation with time trends--1 percentage points per calendar years as compared with .6 percentage points per cohort year. As 
discussed above, this is due in part to the larger number of cohort years that are included in the reform. Also possibly contributing is the collinearity of time and unemployment in the pre-reform period, which produces a positive time trend pre-reform, cancelled out by a more negative time trend post-reform. Nevertheless, in both equations the net change in pension probabilities per year after the reform, including time and cohort trends, is strongly negative--they fell .8-.9 percentage points per year or 14-18 percentage points over the entire post-reform period--for young-old workers. The picture using post-reform year-age dummies for the young-old is consistent — the dummies are gradually phased in from -8 to -18 percentage points between 1987 and 2000 when controlling for time trends, -5 to -13 percentage points when controlling for cohort trend (Table 6). We get conflicting results on whether these effects are stronger, weaker or unchanged, for the old-old.

\section{Results-labor force participation}

Table 7 presents our results on labor force participation rates. Columns 1-3 use time trends as the reform indicator, while columns 4-6 use cohort trends as the reform indicator. Columns 1 and 4 present the model without any individual or macro economic covariates, simply capturing the trends we have already described-falling participation rates pre-reform, rising sharply post-reform. Columns 2 and 5 present the model with covariates but without any pension variables, while columns 3 and 6 add pension amount and interactions effects with pension status before and after the reform.

Comparing equations with and without covariates. First, comparing columns 1 and 4 versus 2 and 5, we see that the explanatory power jumps substantially once individual and economic variables are added, especially in the models with cohort trends. Moreover the absolute size of the trend effect falls substantially. Apparently changes in educational attainment, income and unemployment rates account for much of the aggregate time and cohort trends described in the previous section. But not for all.

Equations without pension variables. Looking next at columns 2 and 5, all the variables discussed above are significant, generally consistent with our expectations, and the coefficients usually differ significantly between those under and over age 50. Each year over age 50 diminishes participation rates by more than 1 percentage point. Highly educated persons are more likely to work during prime age-apparently the substitution effect dominates there-but this effect reverses after age 50-apparently the pension 
eligibility effect dominates there. Non-pension household income has a small negative effect on work propensities, but this effect is cancelled for older workers. As expected, having a wife and children increase work propensities, especially during prime age, and this effect is strengthened when the age difference from spouse is greater. Real growth rate of GDP was practically never significant so we discard it in these specifications. Growth rate using the Hodrick-Prescott filter is sometimes significant, it has the expected positive sign for the prime age males but is negative for those over age 50; we keep it in the equation mainly as a control variable. Each incremental point to unemployment rate, in contrast, depresses participation rates by .2-.3 percentage points for older workers.

Most important for our purposes is the downward time trend and stable cohort trend in participation rates for older men under the old pension system, contrasting with the upward trend (of .4-.5 percentage points per year) after the reform. This trend remains significant and sizeable even after controlling for individual and macroeconomic characteristics.

Equations with pension variables. We investigate this effect further in equations 3 and 6, by introducing pension amount and interactions with pension status. We expect that older workers who receive pensions are less likely to work because they have an alternative source of income and this is one of the reasons for the negative effect of age on participation. The direct negative effect of age should diminish when pension enters the equation, because it is partially replaced by the negative effect of pension. We expect the negative pension effect to be stronger for larger pensions due to the income effect. We also expect that the negative impact of pensioner status on work propensities will become smaller after the reform, because workers can take their pensions, continue working and stop contributing, thereby increasing their net wage in the new system.

This is exactly what we find. Introducing pension status into the equation increases the pseudo $\mathrm{R}^{2}$ substantially, from .4 to $.53-.56$. The pure age effect is cut drastically for young-old workers and a wide gap opens between the age-work profiles of pensioners and nonpensioners. But the gap narrows sharply after age 65-as most pensioners have already stopped working previously while nonpensioners eventually catch up. Pension size has a negative effect on work for prime age men but less so for older individuals, perhaps because of the strong negative interaction effect of age with pension status per se. The direct negative impact of unemployment rate among older 
workers is also reduced when pension status is in the model-probably because unemployment increases pension probabilities and thereby has an indirect negative impact on work propensities.

Most important for our purposes, by interacting pension status with time and cohort we are able to disentangle the response of pensioners and nonpensioners to the reform. Equations 3 and 6 show that virtually the entire downward trend in participation rates of older people before the reform, and even more so the upward trend after the reform, was attributable to pensioners. The old system created incentives for pensioners to stop work early, while the new system gave them incentives to go on working, and they did both. Among young-old pensioners, participation rates rose 2.39 points per calendar year and 1.72 points per cohort year as a result of the reform. (see Tables $8 \mathrm{~A}$ and $8 \mathrm{~B})$. In contrast, work habits of old-old pensioners, who were less likely to be in the new system, changed much less-as predicted. And work propensities of nonpensioners, many of whom are not in any system, actually declined-possibly a response to growing incomes during this period. Since highly educated workers are more likely to be in the system and pensioned, this also means that the positive labor supply effect was concentrated in the group with the highest marginal productivity.

Year-age dummies. We examine the year-age dummies to throw further light on the rate at which the reform effects were phased in. For each calendar year, starting in 1987, we take the subset of older workers who might have been affected by the reformages 50-60 in 1987, 50-61 in 1988, and so on up to 50-75 in 2002. Table 9 splits the sample into two groups, pension recipients and nonpensioners, and runs the equations separately for each group. The nonpensioner group is much larger although the pensioner group includes a disproportionate number of older workers. We use the same control variables that were included in all previous runs, including a time or a cohort trend, but this time all the coefficients are implicitly allowed to vary for pensioners and nonpensioners. Consistent with previous results, labor force participation falls faster with age among pension recipients and is higher among older pensioners with less schooling. Also as before, participation rates fall sharply with unemployment-especially among pensioners. In fact, in general, coefficients have a much larger absolute value for pensioners, perhaps because nonpensioners have less discretion about working, since they have no alternative source of income. 
As we move to the reform effects captured by the dummy variables at the bottom of Table 9, it is clear that these effects are significant only among pensioners, and they are positive only starting in 1994. (This is likely due to the very small sample size of pensioners in the new system and their confounding with old system pensioners, prior to the early 1990's). In any case, by 2000, after controlling for economic cycle and other important covariates, labor force participation rates among the relevant age group had risen 17 percentage points, and had doubled the historic average for pensioners.

\section{Conclusion}

Many countries with aging populations are seeking ways to increase work propensities and delay pension propensities of their older workers. Changes in the behavior of older workers can have a large impact on total labor supply, especially since they are often making an all-or-nothing choice about remaining in the labor force rather than marginal adjustments that workers may make at earlier ages. Chile is an unusual case in that labor force participation rates of its older workers have been increasing and pension probabilities decreasing for the past 15 years. We argue that this is mainly due to incentives and constraints stemming from its social security reform. Older workers seem more responsive than younger workers to tax rates that reduce net wages, perhaps because they have access to an alternative income source in the form of pensions. The high implicit tax rates that are created by many systems have been greatly reduced in Chile, and older workers have responded by increasing their participation rates.

We use probit analysis with three alternative reform indicators-time trends, cohort trends, and year-age dummies - to analyze pension probabilities and labor force participation rates before and after the reform. Pre-reform Chile looked like many European countries today-with early and declining age of pensioning and retirement from the labor force, due to strong incentives from the old social security system. This trend was sharply reversed after the reform. We attribute the increased labor supply of older workers to: 1) postponed pension age because of tighter early withdrawal preconditions and actuarial fair linkages between contributions and benefits; and 2) increased incentives to continue working even if pensioned, because the new system eliminates work penalties that existed previously and exempts pensioners from the pension payroll tax. As a result, many pensioners have continued working. 
The policy lessons for other countries that wish to increase the labor supply of their older workers are obvious. Positive effects are likely if they:

- Raise the age of normal age for pension withdrawals and eligibility requirements for early pensioning;

- Give actuarially fair incremental benefits for postponed withdrawals and additional contributions.

- Exempt older workers from the pension payroll tax, once they have met a target replacement rate.

What is the relative importance of actuarial fairness versus tightened eligibility conditions and exemption from the pension payroll tax, in producing these results? We don't know for sure, since we don't know whether workers start their pensions at the earliest eligible age and whether pensioners continue contributing. However, the fact that the drop in pension probabilities is most clear-cut before the "normal " retirement age and that pensioners have a much stronger work response to the reform than nonpensioners suggests that early retirement constraints and exemption of pensioners from the payroll tax play major roles. It is likely that our probit results understate these behavioral effects due to our inability to identify individuals who are affiliated to the new versus the old systems or not covered by any system at all. A new retrospective data set has just become available that should allow us to probe these issues further. 
Table 1: Age of different cohorts at time of reform and end of our sample

\begin{tabular}{|l|l|l|l|}
\hline Born in: & Age in 1981 & Age in 2002 & $\begin{array}{l}\text { Expected influence } \\
\text { of reform }\end{array}$ \\
\hline $1916-25$ & $56-65$ & $77-86$ & negligible; control \\
\hline $1926-30$ & $51-55$ & $72-76$ & small \\
\hline $1931-35$ & $46-50$ & $67-71$ & moderate \\
\hline $1936-40$ & $41-45$ & $62-66$ & large \\
\hline $1941-45$ & $36-40$ & $57-61$ & larger \\
\hline $1946-50$ & $31-35$ & $52-56$ & just starting to retire \\
\hline
\end{tabular}


Table 2: Male labor force participation rate and pensions by cohort in our sample A. Labor force participation rate among all males

\begin{tabular}{|l|c|c|c|c|c|c|c|c|}
\hline Born & $\mathbf{3 5}-\mathbf{3 9}$ & $\mathbf{4 0}-\mathbf{4 4}$ & $\mathbf{4 5}-\mathbf{4 9}$ & $\mathbf{5 0}-\mathbf{5 4}$ & $\mathbf{5 5}-\mathbf{5 9}$ & $\mathbf{6 0}-\mathbf{6 4}$ & $\mathbf{6 5}-\mathbf{6 9}$ & $\mathbf{7 0}-\mathbf{7 4}$ \\
\hline $\mathbf{1 1 9 1 6}$ & & .980 & .947 & .849 & .797 & .645 & .455 & \\
\hline $\mathbf{1 9 1 6 - 2 0}$ & 0.982 & 0.964 & 0.932 & 0.871 & 0.75 & 0.602 & 0.369 & 0.232 \\
\hline $\mathbf{1 9 2 1 - 2 5}$ & 0.978 & 0.963 & 0.945 & 0.87 & 0.697 & 0.551 & 0.348 & 0.281 \\
\hline $\mathbf{1 9 2 6 - 3 0}$ & 0.978 & 0.969 & 0.953 & 0.852 & 0.731 & 0.605 & 0.453 & 0.258 \\
\hline $\mathbf{1 9 3 1 - 3 5}$ & 0.981 & 0.963 & 0.939 & 0.844 & 0.802 & 0.681 & 0.474 & 0.351 \\
\hline $\mathbf{1 9 3 6 - 4 0}$ & 0.982 & 0.967 & 0.928 & 0.9 & 0.839 & 0.731 & 0.526 & \\
\hline $\mathbf{1 9 4 1 - 4 5}$ & 0.977 & 0.95 & 0.966 & 0.916 & 0.862 & 0.771 & & \\
\hline $\mathbf{1 9 4 6 - 5 0}$ & 0.975 & 0.971 & 0.967 & 0.938 & 0.88 & & & \\
\hline
\end{tabular}

B. Male pension probability

\begin{tabular}{|c|c|c|c|c|c|c|c|c|}
\hline$<\mathbf{1 9 1 6}$ & NA & 0.010 & 0.056 & 0.141 & 0.199 & 0.296 & 0.462 & 0.620 \\
\hline $\mathbf{1 9 1 6 - 2 0}$ & 0.009 & 0.028 & 0.064 & 0.123 & 0.231 & 0.348 & 0.605 & 0.724 \\
\hline $\mathbf{1 9 2 1 - 2 5}$ & 0.011 & 0.032 & 0.064 & 0.134 & 0.298 & 0.415 & 0.643 & 0.712 \\
\hline $\mathbf{1 9 2 6 - 3 0}$ & 0.013 & 0.023 & 0.052 & 0.149 & 0.238 & 0.374 & 0.578 & 0.746 \\
\hline $\mathbf{1 9 3 1 - 3 5}$ & 0.008 & 0.027 & 0.056 & 0.151 & 0.181 & 0.325 & 0.573 & 0.712 \\
\hline $\mathbf{1 9 3 6 - 4 0}$ & 0.010 & 0.017 & 0.049 & 0.086 & 0.173 & 0.272 & 0.526 & \\
\hline $\mathbf{1 9 4 1 - 4 5}$ & 0.009 & 0.023 & 0.026 & 0.08 & 0.144 & 0.278 & & \\
\hline $\mathbf{1 9 4 6 - 5 0}$ & 0.005 & 0.012 & 0.024 & 0.062 & 0.131 & & & \\
\hline
\end{tabular}

C. Male labor force participation by age and cohorts among pensioners

\begin{tabular}{|c|c|c|c|c|c|c|c|c|}
\hline$<\mathbf{1 9 1 6}$ & NA & NA & 0.392 & 0.283 & 0.257 & 0.195 & 0.142 & 0.097 \\
\hline $\mathbf{1 9 1 6 - 2 0}$ & 0.667 & 0.371 & 0.29 & 0.224 & 0.202 & 0.117 & 0.122 & 0.109 \\
\hline $\mathbf{1 9 2 1 - 2 5}$ & 0.50 & 0.393 & 0.41 & 0.269 & 0.164 & 0.123 & 0.139 & 0.124 \\
\hline $\mathbf{1 9 2 6 - 3 0}$ & 0.552 & 0.5 & 0.435 & 0.273 & 0.143 & 0.137 & 0.185 & 0.136 \\
\hline $\mathbf{1 9 3 1 - 3 5}$ & 0.529 & 0.392 & 0.299 & 0.228 & 0.18 & 0.227 & 0.252 & 0.241 \\
\hline $\mathbf{1 9 3 6 - 4 0}$ & 0.368 & 0.333 & 0.242 & 0.183 & 0.347 & 0.325 & 0.24 & \\
\hline $\mathbf{1 9 4 1 - 4 5}$ & 0.176 & 0.100 & 0.462 & 0.33 & 0.407 & 0.425 & & \\
\hline $\mathbf{1 9 4 6 - 5 0}$ & 0 & 0.350 & 0.500 & 0.494 & 0.333 & & & \\
\hline
\end{tabular}

D. Male labor force participation rate among nonpensioners, by age and cohort

\begin{tabular}{|c|c|c|c|c|c|c|c|c|}
\hline$<\mathbf{1 9 1 6}$ & NA & 0.990 & 0.980 & 0.943 & 0.931 & 0.834 & 0.725 & 0.525 \\
\hline $\mathbf{1 9 1 6 - 2 0}$ & 0.985 & 0.981 & 0.976 & 0.961 & 0.914 & 0.861 & 0.748 & 0.555 \\
\hline $\mathbf{1 9 2 1 - 2 5}$ & 0.983 & 0.982 & 0.982 & 0.963 & 0.923 & 0.855 & 0.723 & 0.667 \\
\hline $\mathbf{1 9 2 6 - 3 0}$ & 0.983 & 0.98 & 0.981 & 0.954 & 0.914 & 0.885 & 0.82 & 0.617 \\
\hline $\mathbf{1 9 3 1 - 3 5}$ & 0.985 & 0.979 & 0.977 & 0.954 & 0.94 & 0.9 & 0.773 & 0.625 \\
\hline $\mathbf{1 9 3 6 - 4 0}$ & 0.988 & 0.978 & 0.963 & 0.968 & 0.942 & 0.882 & 0.844 & \\
\hline $\mathbf{1 9 4 1 - 4 5}$ & 0.984 & 0.97 & 0.979 & 0.966 & 0.939 & 0.904 & & \\
\hline $\mathbf{1 9 4 6 - 5 0}$ & 0.98 & 0.979 & 0.978 & 0.968 & 0.962 & & & \\
\hline
\end{tabular}


Table 3: Male labor force participation and pensions by age group in our sample

\begin{tabular}{|c|c|c|c|c|c|c|c|}
\hline \multicolumn{8}{|c|}{ A. Labor force participation-all men } \\
\hline Yr. obs. & $40-44$ & $45-49$ & $50-54$ & $55-59$ & $60-64$ & $65-69$ & $70-74$ \\
\hline 1957-61 & 0.972 & 0.959 & 0.852 & 0.816 & 0.657 & 0.481 & 0.28 \\
\hline $62-66$ & 0.959 & 0.927 & 0.846 & 0.773 & 0.622 & 0.492 & 0.339 \\
\hline $67-71$ & 0.967 & 0.945 & 0.876 & 0.811 & 0.681 & 0.505 & 0.308 \\
\hline $72-76$ & 0.968 & 0.951 & 0.862 & 0.761 & 0.624 & 0.425 & 0.258 \\
\hline $77-81$ & 0.968 & 0.939 & 0.861 & 0.715 & 0.642 & 0.422 & 0.233 \\
\hline $82-86$ & 0.945 & 0.928 & 0.845 & 0.703 & 0.539 & 0.352 & 0.201 \\
\hline 87-91 & 0.97 & 0.957 & 0.892 & 0.791 & 0.591 & 0.355 & 0.203 \\
\hline $92-96$ & 0.968 & 0.968 & 0.906 & 0.834 & 0.677 & 0.457 & 0.271 \\
\hline 97-2002 & 0.966 & 0.97 & 0.938 & 0.863 & 0.723 & 0.461 & 0.287 \\
\hline \multicolumn{8}{|c|}{ B. Pension probability } \\
\hline 1957-61 & 0.018 & 0.044 & 0.119 & 0.138 & 0.196 & 0.317 & 0.374 \\
\hline $62-66$ & 0.035 & 0.068 & 0.148 & 0.215 & 0.289 & 0.387 & 0.474 \\
\hline $67-71$ & 0.025 & 0.063 & 0.125 & 0.216 & 0.308 & 0.419 & 0.62 \\
\hline $72-76$ & 0.026 & 0.05 & 0.13 & 0.225 & 0.354 & 0.538 & 0.63 \\
\hline $77-81$ & 0.015 & 0.063 & 0.155 & 0.288 & 0.318 & 0.537 & 0.694 \\
\hline $82-86$ & 0.027 & 0.051 & 0.153 & 0.259 & 0.422 & 0.626 & 0.745 \\
\hline $87-91$ & 0.011 & 0.032 & 0.096 & 0.183 & 0.381 & 0.629 & 0.757 \\
\hline $92-96$ & 0.009 & 0.02 & 0.081 & 0.166 & 0.331 & 0.579 & 0.712 \\
\hline 97-2002 & 0.009 & 0.024 & 0.063 & 0.154 & 0.285 & 0.585 & 0.733 \\
\hline
\end{tabular}

\begin{tabular}{|c|c|c|c|c|c|c|c|}
\hline \multicolumn{6}{|c|}{ C. Labor force participation among pensioners } \\
\hline $\mathbf{1 9 5 7 - 6 1}$ & 0.348 & 0.404 & 0.235 & 0.22 & 0.183 & 0.145 & 0.066 \\
\hline $\mathbf{6 2 - 6 6}$ & 0.333 & 0.327 & 0.291 & 0.232 & 0.183 & 0.131 & 0.11 \\
\hline $\mathbf{6 7 - 7 1}$ & 0.549 & 0.385 & 0.249 & 0.305 & 0.213 & 0.142 & 0.112 \\
\hline $\mathbf{7 2 - 7 6}$ & 0.396 & 0.4 & 0.255 & 0.215 & 0.181 & 0.146 & 0.102 \\
\hline $\mathbf{7 7 - 8 1}$ & 0.308 & 0.393 & 0.315 & 0.176 & 0.162 & 0.142 & 0.102 \\
\hline $\mathbf{8 2 - 8 6}$ & 0.13 & 0.2 & 0.201 & 0.14 & 0.113 & 0.111 & 0.09 \\
\hline $\mathbf{8 7 - 9 1}$ & 0.444 & 0.37 & 0.178 & 0.155 & 0.141 & 0.145 & 0.09 \\
\hline $\mathbf{9 2 - 9 6}$ & 0.333 & 0.517 & 0.336 & 0.259 & 0.196 & 0.194 & 0.122 \\
\hline $\mathbf{9 7 - 2 0 0 2}$ & 0.55 & 0.578 & 0.46 & 0.436 & 0.332 & 0.236 & 0.162 \\
\hline
\end{tabular}

D. Labor force participation among nonpensioners

\begin{tabular}{|c|c|c|c|c|c|c|c|}
\hline $\mathbf{1 9 5 7 - 6 1}$ & 0.983 & 0.984 & 0.936 & 0.912 & 0.773 & 0.637 & 0.408 \\
\hline $\mathbf{6 2 - 6 6}$ & 0.981 & 0.971 & 0.943 & 0.921 & 0.801 & 0.719 & 0.547 \\
\hline $\mathbf{6 7 - 7 1}$ & 0.978 & 0.982 & 0.966 & 0.951 & 0.89 & 0.766 & 0.627 \\
\hline $\mathbf{7 2 - 7 6}$ & 0.984 & 0.981 & 0.952 & 0.919 & 0.866 & 0.75 & 0.523 \\
\hline $\mathbf{7 7 - 8 1}$ & 0.978 & 0.976 & 0.961 & 0.933 & 0.866 & 0.747 & 0.53 \\
\hline $\mathbf{8 2 - 8 6}$ & 0.967 & 0.968 & 0.962 & 0.9 & 0.85 & 0.753 & 0.527 \\
\hline $\mathbf{8 7 - 9 1}$ & 0.976 & 0.977 & 0.968 & 0.933 & 0.867 & 0.711 & 0.554 \\
\hline $\mathbf{9 2 - 9 6}$ & 0.974 & 0.977 & 0.956 & 0.948 & 0.915 & 0.818 & 0.638 \\
\hline $\mathbf{9 7 - 2 0 0 2}$ & 0.97 & 0.98 & 0.97 & 0.941 & 0.879 & 0.779 & 0.63 \\
\hline
\end{tabular}


Table 4: Variable Definitions and Sample Means

Variables to capture the age profile of participation and pension probabilities

\begin{tabular}{|c|c|c|}
\hline Age50 & Age- 50 , or 0 if age $<50$ & Varies between 1 and 49 \\
\hline Age65 & Age-65, or 0 if age $<65$ & Varies between 1 and 34 \\
\hline \multicolumn{3}{|c|}{ Variables to capture the effect of individual and household characteristics } \\
\hline Ed6 & Dummy $=1$ if schooling $<=6$ & 0.35 \\
\hline Ed12 & Dummy $=1$ if schooling $>=12$ & 0.37 \\
\hline Hh income & $\begin{array}{l}\text { Real household monthly } \\
\text { income (minus own labor and } \\
\text { own pension income) per } \\
\text { capita in } 1977 \text { pesos }\end{array}$ & 85.22 \\
\hline Pen income & $\begin{array}{l}\text { Real pension monthly income } \\
\text { in } 1977 \text { pesos per pensioner }\end{array}$ & 309.22 \\
\hline Pen & $\begin{array}{c}\text { Dummy }=1 \text { if individuals } \\
\text { receives pension }\end{array}$ & 0.14 \\
\hline \#children & \# of children younger than 18 & 1.3 \\
\hline Spouse present & $\begin{array}{l}\text { Dummy=1 if the individual } \\
\text { has a spouse living in hh }\end{array}$ & 0.79 \\
\hline Spousal age diff & Own age-spouse age & 3.13 \\
\hline d50 & 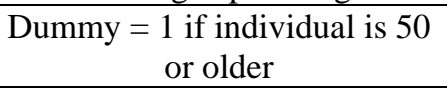 & 0.39 \\
\hline d65 & $\begin{array}{c}\text { Dummy }=1 \text { if individual is } 65 \\
\text { or older }\end{array}$ & 0.13 \\
\hline \multicolumn{3}{|c|}{ Variables to capture macroeconomic effects } \\
\hline UnE rate & Unemployment rate in \% & 10.3 \\
\hline $\begin{array}{l}\text { Deviations H-P } \\
\text { growth rate }\end{array}$ & $\begin{array}{l}\text { Difference in logs between } \\
\text { real annual GDP and the } \\
\text { Hoddrick -Prescott filter. }\end{array}$ & 0.001 \\
\hline \multicolumn{3}{|c|}{ Variables to capture the impact of reform } \\
\hline Time & Year of observation - 1960 & Varies between 0 and 42 \\
\hline Time87 & Year of observation - 1986 & Varies between 0 and 16 \\
\hline Coh & $\begin{array}{r}\text { Year of birth-1916, or } 0 \text { if } \\
\text { born before } 1916 \\
\end{array}$ & Varies between 0 and 36 \\
\hline Coh31 & $\begin{array}{r}\text { Year of birth-1930, or } 0 \text { if } \\
\text { born before } 1931\end{array}$ & Varies between 0 and 22 \\
\hline $\begin{array}{l}\text { Year-age } \\
\text { dummies }\end{array}$ & $\begin{array}{r}\text { Relevant age group for each } \\
\text { years } 1987-2002\end{array}$ & \\
\hline
\end{tabular}


Table 5: dProbit results ${ }^{\mathrm{a}}$ : Pension rates males $50+$ pre- and post-reform Reform Effects are captured by changes in time trend and cohort trend

\begin{tabular}{|l|c|c|}
\hline & $\begin{array}{c}\text { Controlling } \\
\text { for time trend } \\
\text { (1) }\end{array}$ & $\begin{array}{c}\text { Controlling for } \\
\text { cohort trend } \\
\text { (2) }\end{array}$ \\
\hline Age50 & 2.69 & 2.66 \\
\hline Age65 & -1.45 & $-0.11^{* *}$ \\
\hline Ed6 & -6.42 & -6.81 \\
\hline Ed12 & $0.16^{* *}$ & $0.45^{* *}$ \\
\hline Hh income & -0.02 & -0.02 \\
\hline \#children & -1.87 & -1.95 \\
\hline Spouse present & 8.06 & 7.33 \\
\hline Spousal age diff & -0.40 & -0.43 \\
\hline UnE rate & 0.22 & 0.43 \\
\hline Time & 0.16 & \\
\hline Time*d65 & 0.57 & \\
\hline Time87 & -1.03 & \\
\hline Time87*d65 & 0.49 & -0.17 \\
\hline Coh & & 1.04 \\
\hline Coh*d65 & & -0.63 \\
\hline Coh31 & & -1.65 \\
\hline Coh31*d65 & & 0.34 \\
\hline & & 0.31 \\
\hline observed P & 0.35 & 0.2 \\
\hline predicted P (at Xbar) & 0.32 & 34,706 \\
\hline & & \\
\hline Pseudo R & & \\
\hline \# of observations & 0.2 & \\
\hline a All 0 ffici & 37,167 & \\
\hline
\end{tabular}

a All coefficients are reported as percentage points

$P$ values of estimated coefficients are smaller than 0.001 unless indicated otherwise

* P value between .05 and .10

** $\mathrm{P}$ value above .10 (hypothesis of coeff $=0$ cannot be rejected) 
Table 6: dProbit results ${ }^{\mathrm{a}}$ : Pension rates males $50+$ pre- and post-reform Reform Effects are captured by Age-Year Dummies

\begin{tabular}{|c|c|c|}
\hline & $\begin{array}{c}\text { Controlling for } \\
\text { time trend } \\
(1)\end{array}$ & $\begin{array}{c}\text { Controlling for } \\
\text { cohort trend } \\
(1 \\
\end{array}$ \\
\hline Age50 & 2.76 & 2.91 \\
\hline Age65 & -1.59 & -0.47 \\
\hline Ed6 & -6.52 & -6.89 \\
\hline Ed12 & $0.29 * *$ & $0.47 * *$ \\
\hline Hh income & -0.02 & -0.02 \\
\hline \#children & -1.98 & -1.94 \\
\hline Spouse present & 7.96 & 7.46 \\
\hline Spousal age diff & -0.39 & -0.44 \\
\hline UnE rate & $0.07 * *$ & 0.31 \\
\hline Time & 0.31 & \\
\hline Time*d65 & 0.38 & \\
\hline Coh & & $-0.03^{* *}$ \\
\hline Coh*d65 & & 0.77 \\
\hline \multicolumn{3}{|l|}{ Reform Effect } \\
\hline $50-60$ in 87 & -7.61 & -4.72 \\
\hline $50-61$ in 88 & -10.41 & -6.95 \\
\hline $50-62$ in 89 & -10.44 & -6.40 \\
\hline $50-63$ in 90 & -7.86 & -3.62 \\
\hline $50-64$ in 91 & -12.07 & -7.54 \\
\hline $50-65$ in 92 & -15.17 & -10.05 \\
\hline $50-65$ in 93 & -14.88 & -9.68 \\
\hline $50-65$ in 94 & -11.90 & -6.04 \\
\hline $50-65$ in 95 & -13.37 & -7.42 \\
\hline $50-65$ in 96 & -11.32 & -5.00 \\
\hline $50-65$ in 97 & -14.53 & -8.29 \\
\hline $50-65$ in 98 & -16.85 & -10.74 \\
\hline $50-65$ in 99 & -13.35 & -8.42 \\
\hline $50-65$ in 2000 & -18.15 & -13.18 \\
\hline $50-65$ in 2001 & -14.48 & -9.17 \\
\hline $50-65$ in 2002 & -14.13 & -8.24 \\
\hline $66+$ after 1993 & $* *$ & $* *$ \\
\hline & & \\
\hline observed P & 0.35 & 0.34 \\
\hline predicted P (at Xbar) & 0.32 & 0.31 \\
\hline Pseudo $\mathbf{R}^{2}$ & 0.2 & 0.21 \\
\hline \# of observations & 37,167 & 34,706 \\
\hline
\end{tabular}

a $P$ values of estimated coefficients are smaller than 0.001 unless indicated otherwise

* P value between .05 and .10

** $\mathrm{P}$ value above .10 (hypothesis of coeff $=0$ cannot be rejected) 
Table 7: dProbit results ${ }^{\mathrm{a}}$ : Labor force participation rates, males 30+ pre- and post-reform using time trend and cohort trend as reform indicators

\begin{tabular}{|c|c|c|c|c|c|c|}
\hline & \multicolumn{3}{|c|}{ With time trends } & \multicolumn{3}{|c|}{ With cohort trends } \\
\hline & $\begin{array}{c}\text { (1) } \\
\text { trends } \\
\text { only }\end{array}$ & $\begin{array}{c}\text { (2) } \\
\text { with } \\
\text { covariates }\end{array}$ & $\begin{array}{c}\text { (3) } \\
\text { pension } \\
\text { controls }\end{array}$ & $\begin{array}{c}\text { (4) } \\
\text { trends } \\
\text { only }\end{array}$ & $\begin{array}{c}\text { (5) } \\
\text { with } \\
\text { covariates }\end{array}$ & $\begin{array}{c}\text { (6) } \\
\text { pension } \\
\text { controls }\end{array}$ \\
\hline Age50 & & -1.40 & -0.60 & & -1.23 & -0.23 \\
\hline Age65 & & 0.18 & -0.51 & & $-0.08 * *$ & -0.94 \\
\hline Pen*age50 & & & -1.08 & & & -1.62 \\
\hline Pen*age65 & & & 1.49 & & & 2.52 \\
\hline Ed6 & & -1.95 & -1.71 & & -1.71 & -1.52 \\
\hline Ed6*d50 & & 5.31 & $5.70 * *$ & & 4.97 & $5.26 * *$ \\
\hline Ed12 & & 2.30 & -0.52 & & 2.03 & -0.38 \\
\hline Ed12*d50 & & -5.71 & -5.27 & & -5.79 & -5.18 \\
\hline Pen income & & & -0.08 & & & -0.07 \\
\hline Pen income*d50 & & & 0.07 & & & 0.06 \\
\hline Hh income & & -0.003 & -0.003 & & -0.003 & -0.003 \\
\hline Hh inc*d50 & & 0.005 & $0.001^{* *}$ & & $0.005^{* *}$ & 0.002 \\
\hline \#children & & 0.94 & 0.79 & & 0.87 & 0.73 \\
\hline \#children*d50 & & $-0.22 * *$ & -0.49 & & -0.20 & -0.50 \\
\hline Spouse present & & 11.74 & 12.93 & & 11.09 & 12.13 \\
\hline Spouse*d50 & & -8.33 & -5.76 & & -8.07 & -5.76 \\
\hline Spousal age diff & & 0.12 & 0.15 & & 0.11 & 0.13 \\
\hline Spousal age diff*d50 & & 0.14 & $0.02 * *$ & & 0.12 & $0.02 * *$ \\
\hline UnE rate & & $0.02 * *$ & 0.13 & & $0.04^{* *}$ & 0.13 \\
\hline UnE rate*d50 & & -0.22 & -0.28 & & -0.35 & -0.37 \\
\hline $\begin{array}{l}\text { Deviations } \mathrm{H}-\mathrm{P} \\
\text { growth rate }\end{array}$ & & $6.22 *$ & 13.49 & & 6.63 & 12.87 \\
\hline $\begin{array}{l}\text { Deviations H-P } \\
\text { growth*d50 }\end{array}$ & & -10.04 & -13.84 & & -14.69 & -17.64 \\
\hline Time*d50 & -0.92 & -0.09 & 0.32 & & & \\
\hline Time*d65 & -1.37 & -0.08 & -0.21 & & & \\
\hline Time87*d50 & 2.02 & 0.61 & -0.43 & & & \\
\hline Time87*d65 & 1.70 & -0.23 & 0.39 & & & \\
\hline Pen*time*d50 & & & -1.23 & & & \\
\hline Pen*time*d65 & & & 0.90 & & & \\
\hline Pen*time87*d50 & & & 2.81 & & & \\
\hline Pen*time87*d65 & & & -1.99 & & & \\
\hline Coh*d50 & & & & -1.07 & 0.02 & 0.47 \\
\hline Coh*d65 & & & & -2.66 & $-0.12 * *$ & -0.49 \\
\hline Coh31*d50 & & & & 2.32 & 0.34 & -0.48 \\
\hline Coh31*d65 & & & & 7.18 & $0.33 * *$ & $0.65 *$ \\
\hline Pen*coh*d50 & & & & & & -1.49 \\
\hline Pen*coh*d65 & & & & & & 1.91 \\
\hline Pen*coh31*d50 & & & & & & 2.20 \\
\hline Pen*coh31*d65 & & & & & & -2.14 \\
\hline Pseudo $\mathbf{R}^{2}$ & .28 & .4 & .56 & .08 & .37 & .53 \\
\hline \# of observations & 95,385 & 95,385 & 95,074 & 92,924 & 92,924 & 92,614 \\
\hline
\end{tabular}


Table 8A: Time trend: Change per calendar year in participation rates for older individuals, before and after reform (based on probit estimates, column 3, Table 7) (in percentage points)

\begin{tabular}{|l|c|c|c|}
\hline & Nonpensioners & Pensioners & $\begin{array}{l}\text { Difference due } \\
\text { to pensioner } \\
\text { status }\end{array}$ \\
\hline \multicolumn{3}{|c|}{ Ages } \\
\hline Before reform & 0.32 & -0.92 & -1.23 \\
\hline After reform & -0.11 & 1.47 & 1.58 \\
\hline $\begin{array}{l}\text { Net change } \\
\text { after reform }\end{array}$ & $-0.43 \quad$ Ages 65+ \\
\hline \multicolumn{3}{|c|}{2.39} & 2.81 \\
\hline Before reform & $0.11 \quad 0.22$ & -0.33 \\
\hline After reform & $0.07 \quad 0.56$ & 0.50 \\
\hline $\begin{array}{l}\text { Net change } \\
\text { after reform }\end{array}$ & -0.04 & 0.78 & 0.83 \\
\hline
\end{tabular}

Table 8B: Cohort trend: Change per birth year in participation rates for older individuals, before and after reform (based on probit estimates, column 6, Table 7) (in percentage points)

\begin{tabular}{|l|c|c|c|}
\hline & Nonpensioners & Pensioners & $\begin{array}{l}\text { Difference due } \\
\text { to pensioner } \\
\text { status }\end{array}$ \\
\hline \multicolumn{3}{|c|}{ Ages } \\
\hline Before reform & $0.47 \quad-64$ \\
\hline After reform & -0.01 & 0.70 & -1.49 \\
\hline $\begin{array}{l}\text { Net change } \\
\text { after reform }\end{array}$ & $-0.48 \quad$ Ages 65+ \\
\hline \multicolumn{3}{|c|}{0.71} \\
\hline Before reform & $-0.01 \quad 0.41$ & 2.20 \\
\hline After reform & $0.16 \quad 0.65$ & 0.43 \\
\hline $\begin{array}{l}\text { Net change } \\
\text { after reform }\end{array}$ & 0.18 & 0.24 & 0.49 \\
\hline
\end{tabular}


Table 9: Probit results ${ }^{\mathrm{a}}$ : Labor force participation rates males 30+ Reform Effect captured by age-year dummies on relevant population

\begin{tabular}{|c|c|c|c|c|}
\hline & \multicolumn{2}{|c|}{ Pension Recipients } & \multicolumn{2}{|c|}{ Non Pensioners } \\
\hline & $\begin{array}{c}\text { Time } \\
\text { trend }\end{array}$ & $\begin{array}{c}\text { Cohort } \\
\text { trend }\end{array}$ & $\begin{array}{l}\text { Time } \\
\text { trend }\end{array}$ & $\begin{array}{c}\text { Cohort } \\
\text { trend }\end{array}$ \\
\hline Age50 & -0.75 & -0.71 & -0.36 & -0.33 \\
\hline Age65 & $* *$ & $* *$ & -0.07 & -0.09 \\
\hline Ed6 & $* *$ & $* *$ & -1.28 & -1.27 \\
\hline Ed6*d50 & 11.66 & 12.19 & 1.42 & 1.30 \\
\hline Ed12 & $* *$ & $* *$ & 0.47 & 0.54 \\
\hline Ed12*d50 & -7.79 & -8.43 & -0.33 & -0.23 \\
\hline Pen income & -0.01 & -0.01 & & \\
\hline Pen income*d50 & $* *$ & $* *$ & & \\
\hline Hh income & 0.03 & 0.04 & -0.002 & -0.002 \\
\hline Hh inc*d50 & -0.02 & -0.03 & -0.001 & 0.000 \\
\hline \#children & 1.96 & 2.07 & 0.37 & 0.35 \\
\hline \#children*d50 & -1.05 & $-1.26 *$ & $-0.19 *$ & -0.19 \\
\hline Spouse present & 8.27 & 8.70 & 6.27 & 5.95 \\
\hline Spouse*d50 $^{*}$ & $-4.81^{*}$ & $-4.79 *$ & -1.37 & -1.28 \\
\hline Spousal age diff & $* *$ & $* *$ & 0.06 & 0.06 \\
\hline Spousal age diff*d50 & $* *$ & $* *$ & $* *$ & $* *$ \\
\hline UnE rate & -0.58 & -0.61 & -0.04 & -0.04 \\
\hline UnE rate*d50 & $0.32 *$ & $0.30 *$ & -0.05 & -0.004 \\
\hline Deviations H-P growth rate & $* *$ & $* *$ & $* *$ & $* *$ \\
\hline Deviations H-P growth*d50 & $* *$ & $* *$ & $* *$ & $* *$ \\
\hline Time*d50 & $* *$ & & 0.04 & \\
\hline Time*d65 & $* *$ & & $* *$ & \\
\hline Coh*d50 & & 0.06 & & $* *$ \\
\hline Coh*d65 & & -0.11 & & $* *$ \\
\hline \multicolumn{5}{|l|}{ Reform effect } \\
\hline $50-60$ in 87 & -7.45 & -8.02 & $* *$ & $* *$ \\
\hline $50-61$ in 88 & -7.17 & -7.78 & $* *$ & $* *$ \\
\hline $50-62$ in 89 & -7.43 & -8.10 & $* *$ & $* *$ \\
\hline $50-63$ in 90 & $* *$ & $* *$ & $* *$ & $* *$ \\
\hline $50-64$ in 91 & $* *$ & $* *$ & -1.08 & $* *$ \\
\hline $50-65$ in 92 & $-6.50 *$ & -7.16 & $* *$ & $* *$ \\
\hline $50-66$ in 93 & $* *$ & $* *$ & $* *$ & $* *$ \\
\hline $50-67$ in 94 & $5.77 *$ & 5.70 & $* *$ & 1.02 \\
\hline $50-68$ in 95 & $5.65 *$ & 5.82 & $* *$ & 0.79 \\
\hline $50-69$ in 96 & 8.33 & 8.82 & -2.21 & $* *$ \\
\hline $50-70$ in 97 & 7.60 & 8.07 & $* *$ & $* *$ \\
\hline $50-71$ in 98 & $5.44^{*}$ & 5.93 & $* *$ & $* *$ \\
\hline $50-72$ in 99 & 14.86 & 16.31 & 0.89 & 1.21 \\
\hline $50-73$ in 2000 & 15.12 & 18.61 & $* *$ & 1.01 \\
\hline $50-74$ in 2001 & 17.03 & 17.17 & $* *$ & $* *$ \\
\hline $50-75$ in 2002 & 15.76 & 16.64 & $* *$ & 0.89 \\
\hline observed P & 0.17 & 0.18 & 0.95 & 0.96 \\
\hline predicted P (at Xbar) & 0.15 & 0.16 & 0.98 & 0.98 \\
\hline Pseudo $\mathbf{R}^{2}$ & 0.09 & 0.09 & 0.29 & 0.25 \\
\hline \# of observations & 13,721 & 12,357 & 81,353 & 80,257 \\
\hline
\end{tabular}


Figure 1: Male labor force participation by age and cohort in our sample

labor force participation rate, by age and cohort

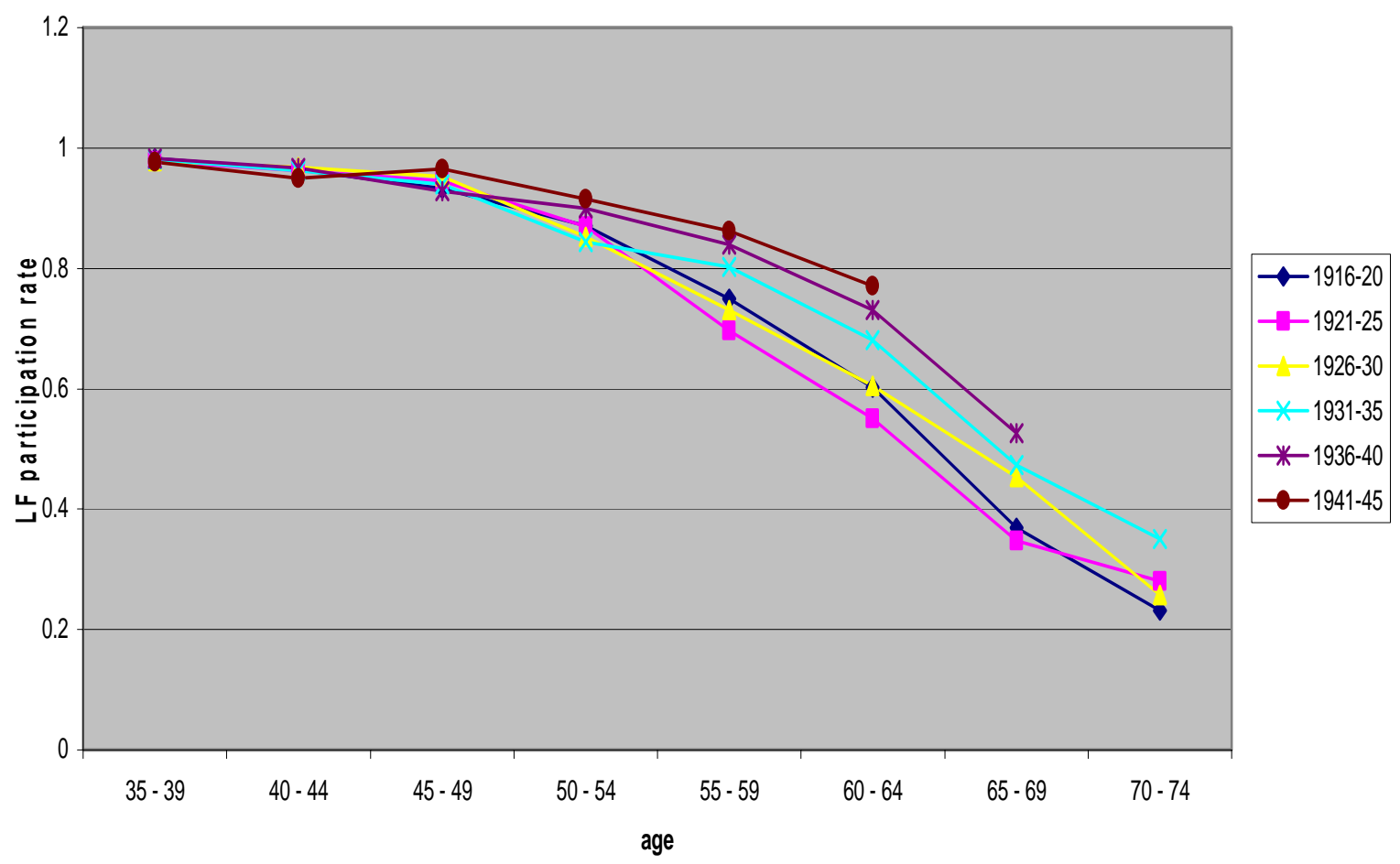


Figure 2: Age-pension profiles by cohort

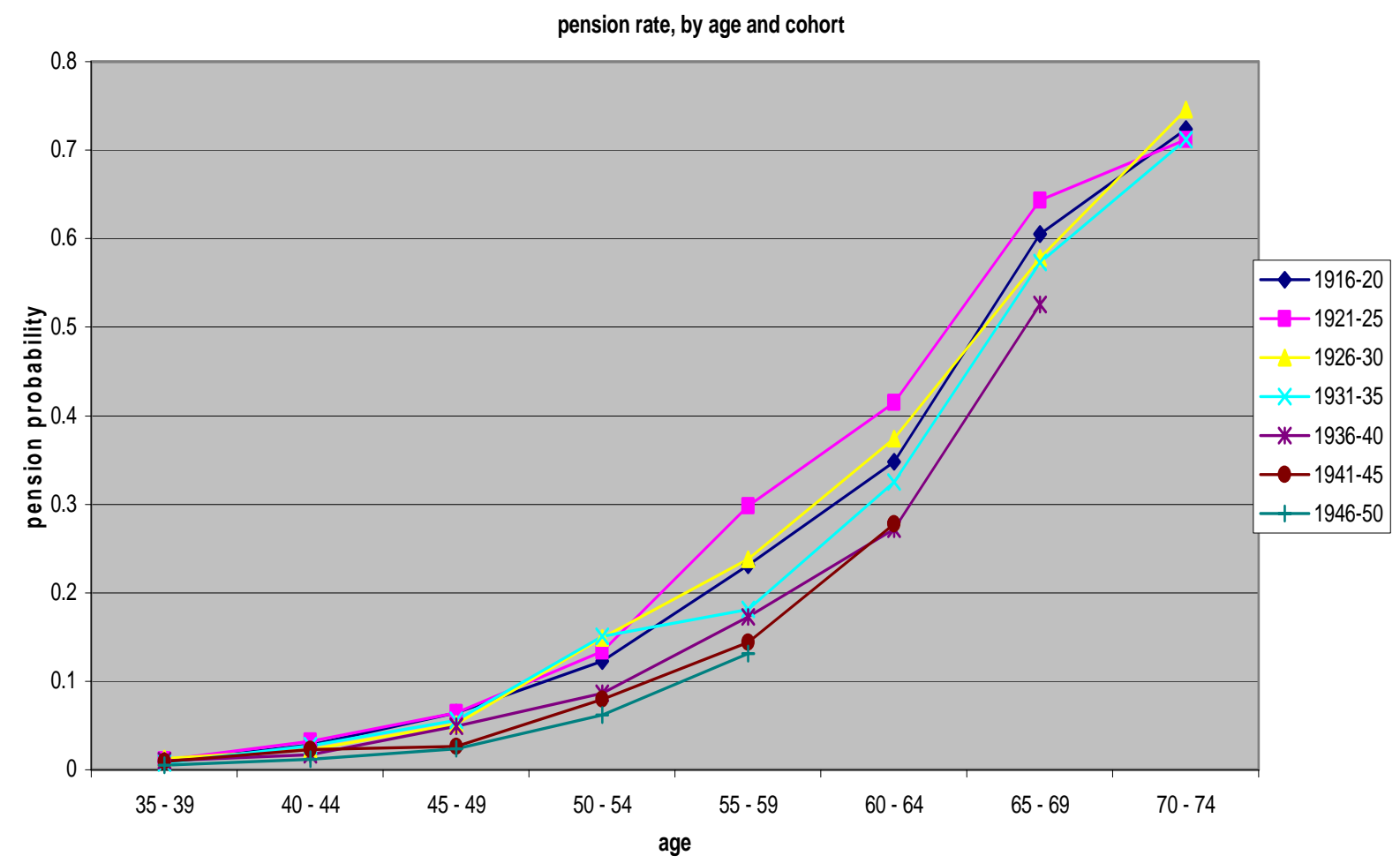


Figure 3: Male labor force participation rates by age groups over time

labor force participation rate by age groups

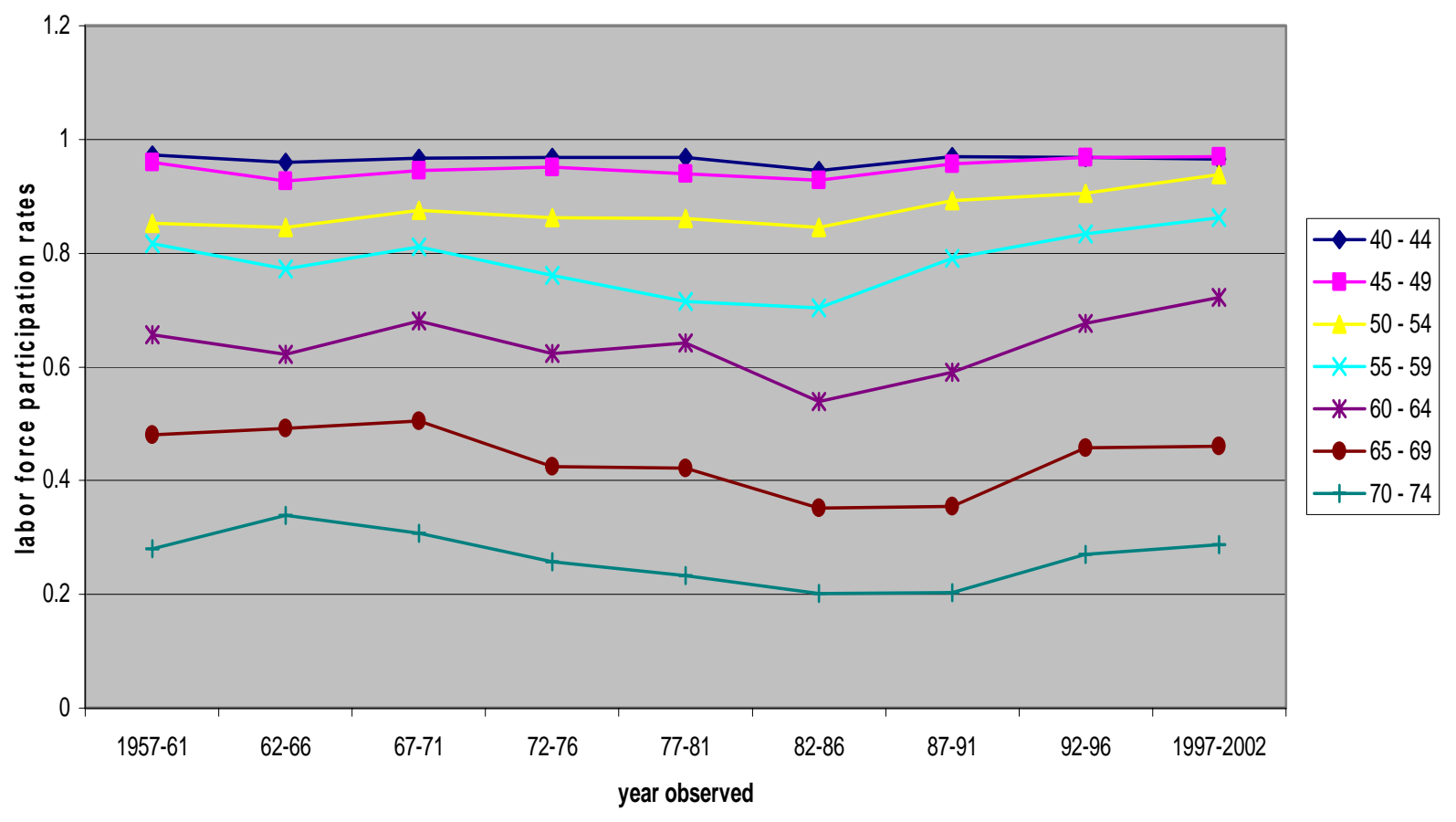


Figure 4: Labor force participation rates by age group: Pensioners and nonpensioners compared

Participation rates by age groups, pensioners and non-pensioners compared

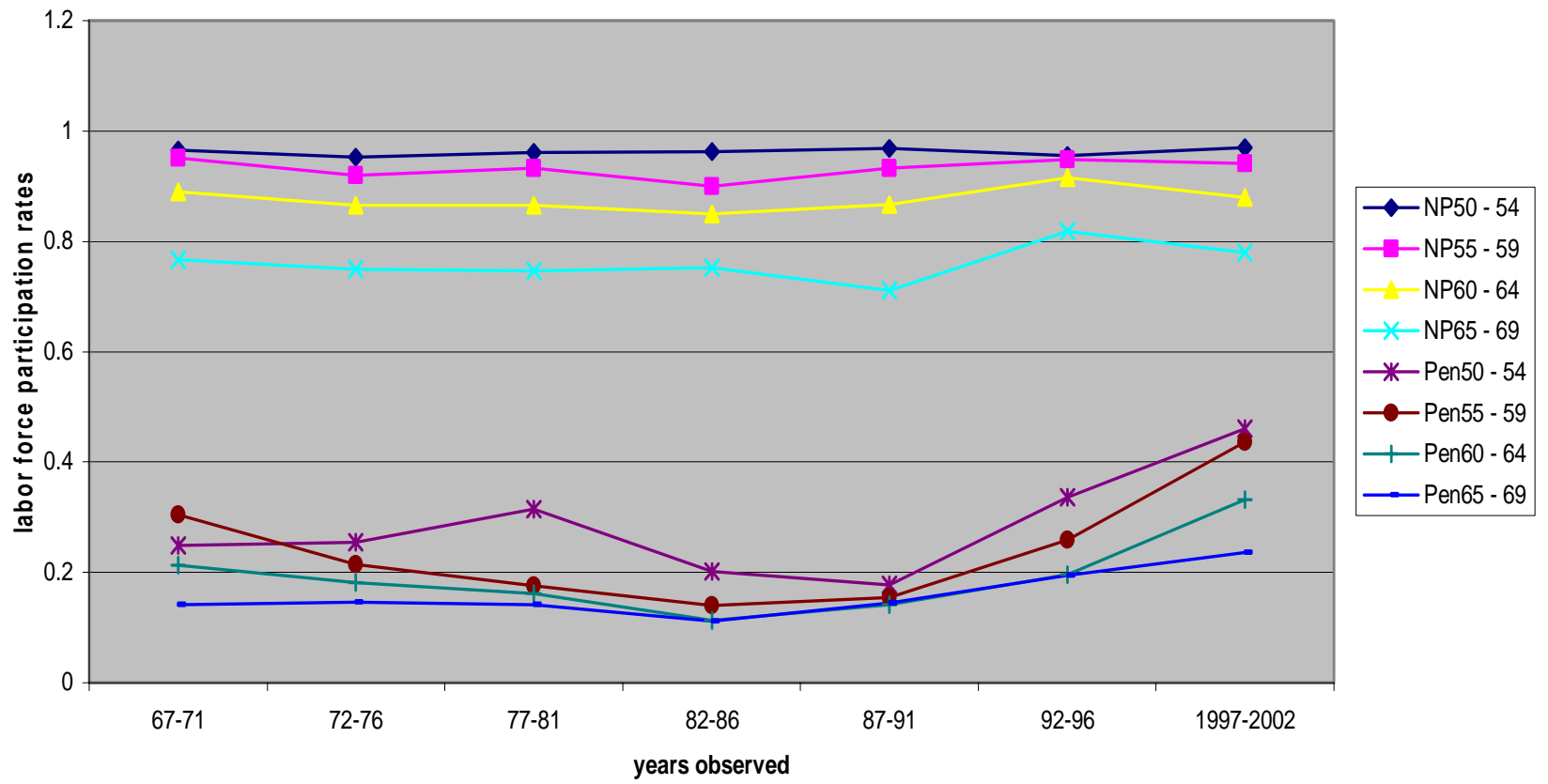


Figure 5: Pension probabilities by age group over time

pension probabilities by age group over time

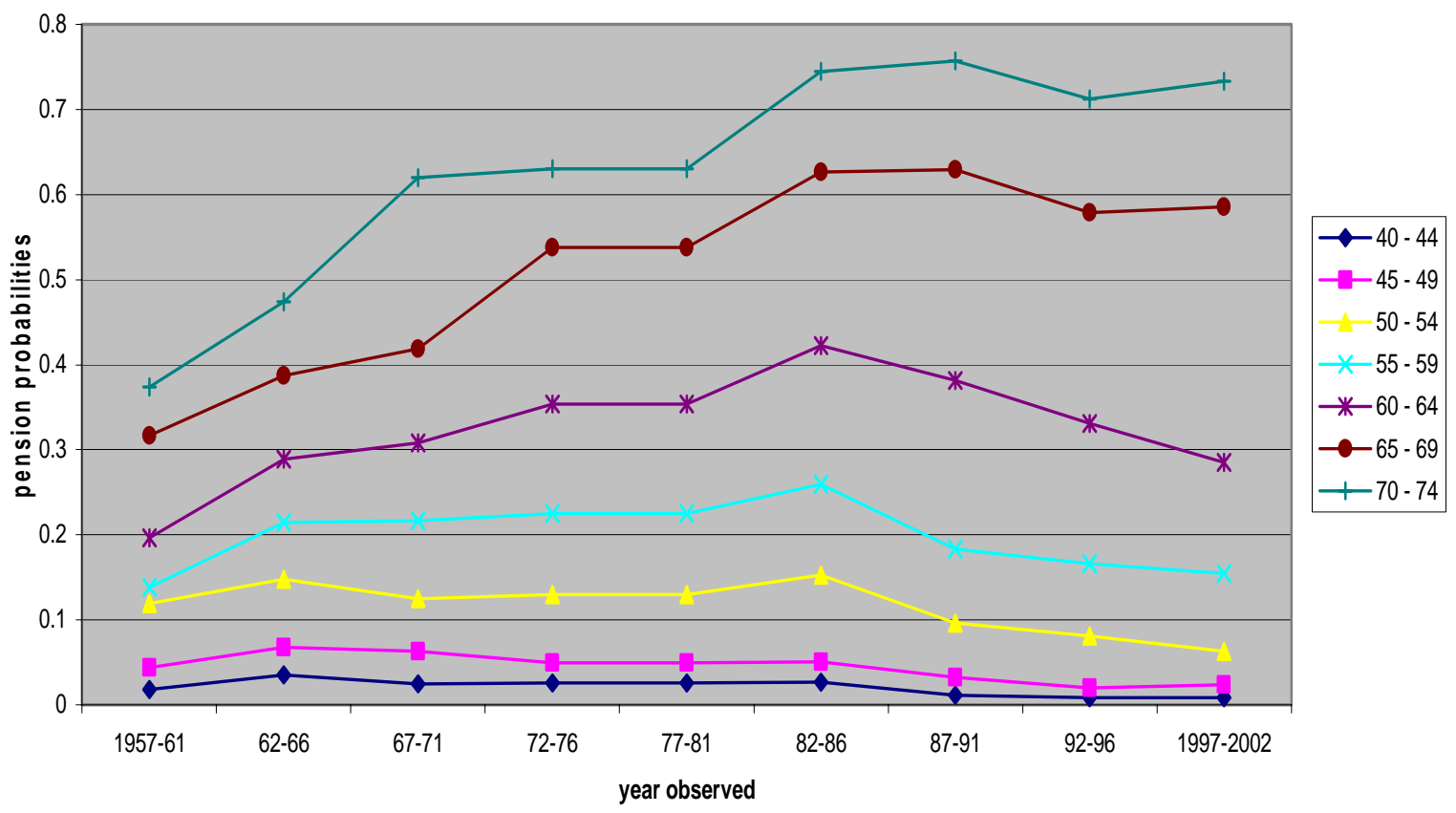


Figure 6: Hazard rates of dropping out of labor force were higher pre-reform

hazard of dropping out of labor force, pre- minus post-reform cohorts

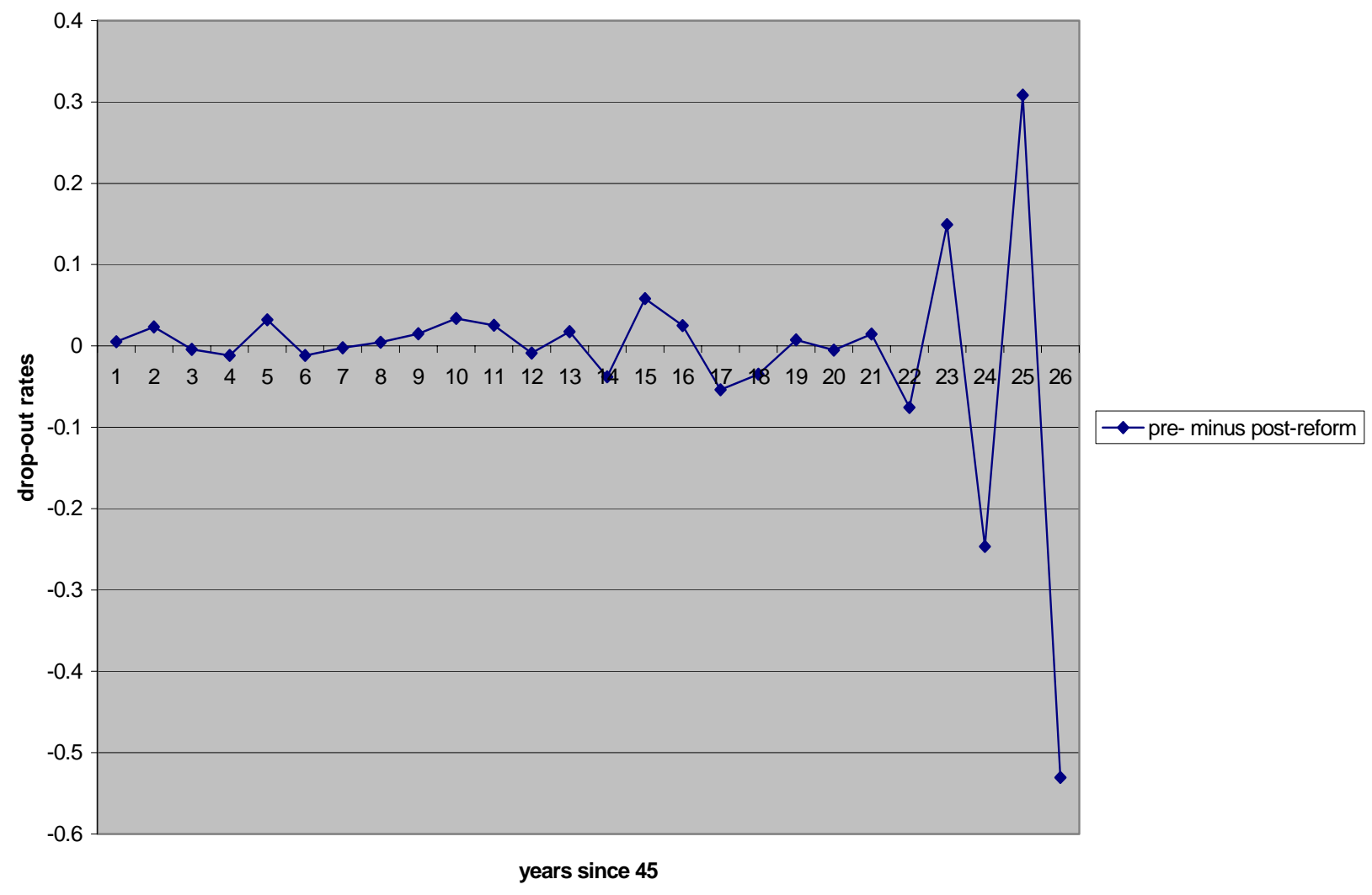


Figure 7: Survival rates in labor force for older workers are higher post reform

survival rates in labor force, post- minus pre-reform

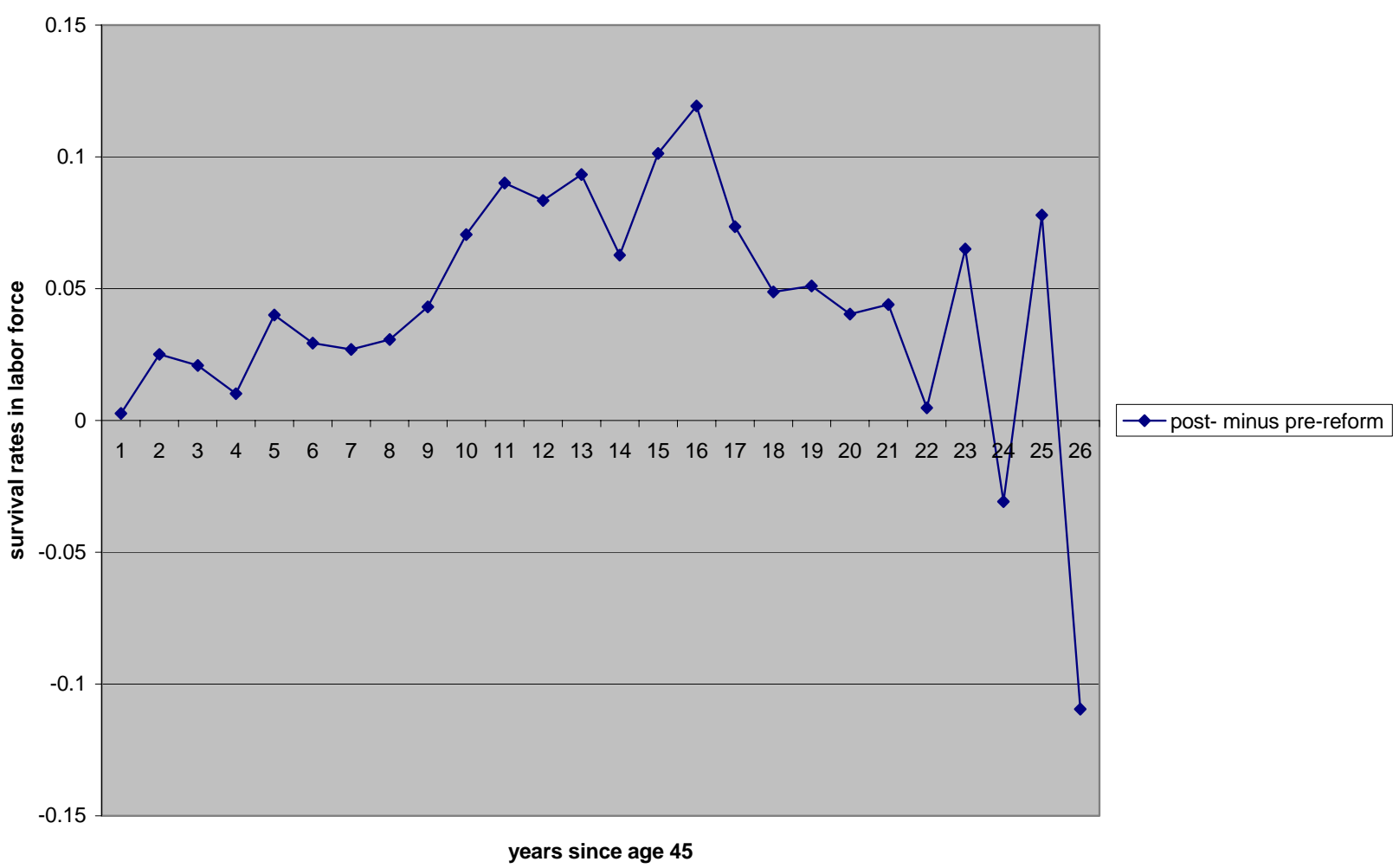


Figure 8: Survival rates in labor force pre and post-reform, Differences are significant among pensioners

survival rates in labor force pre- and post-reform, pensioners vs. nonpensioners

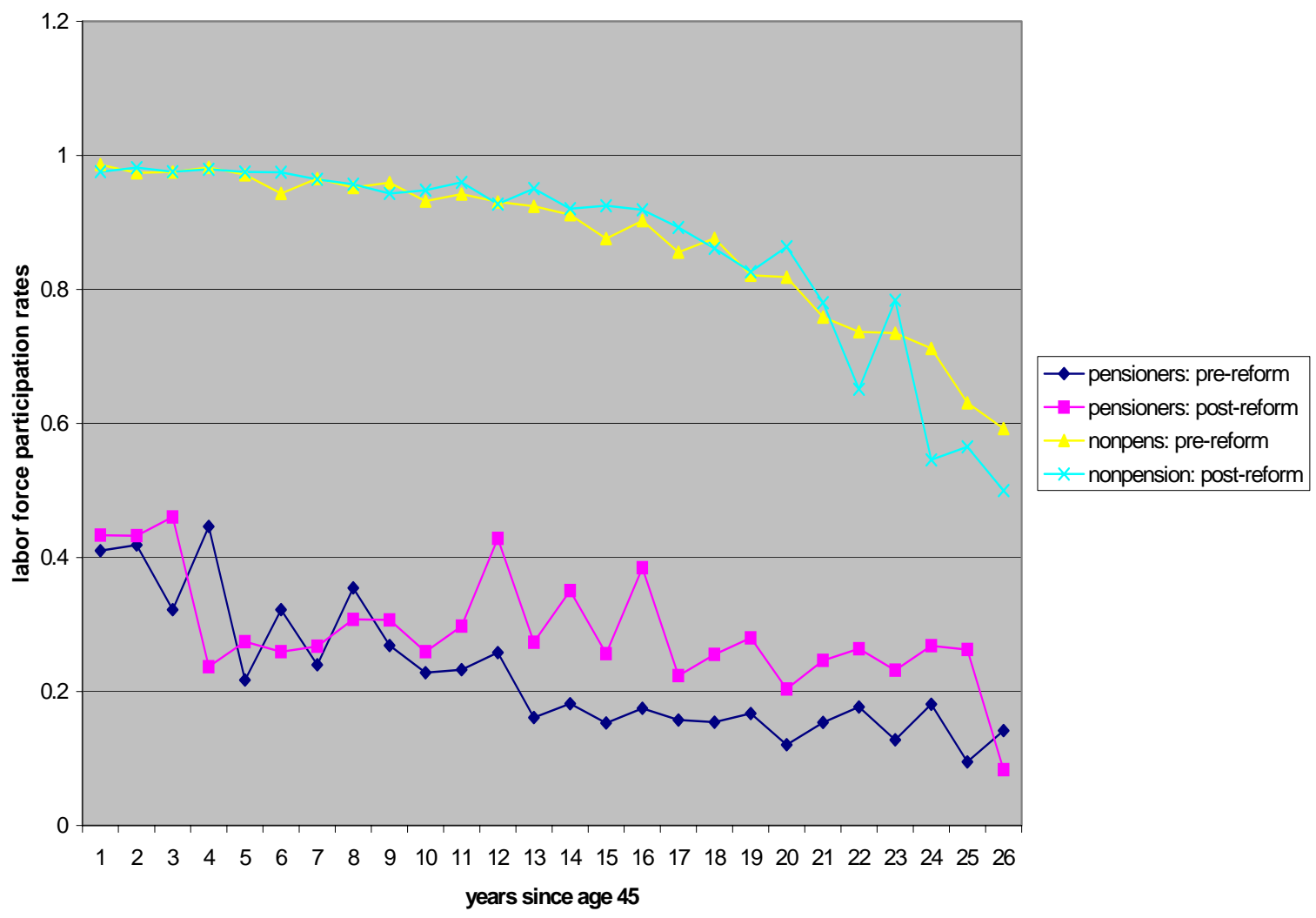


Figure 9: Change in labor force survival rates, post minus pre-reform, pensioners vs. non-pensioners

Survival rates post minus pre-reform, pensioners vs. nonpensioners

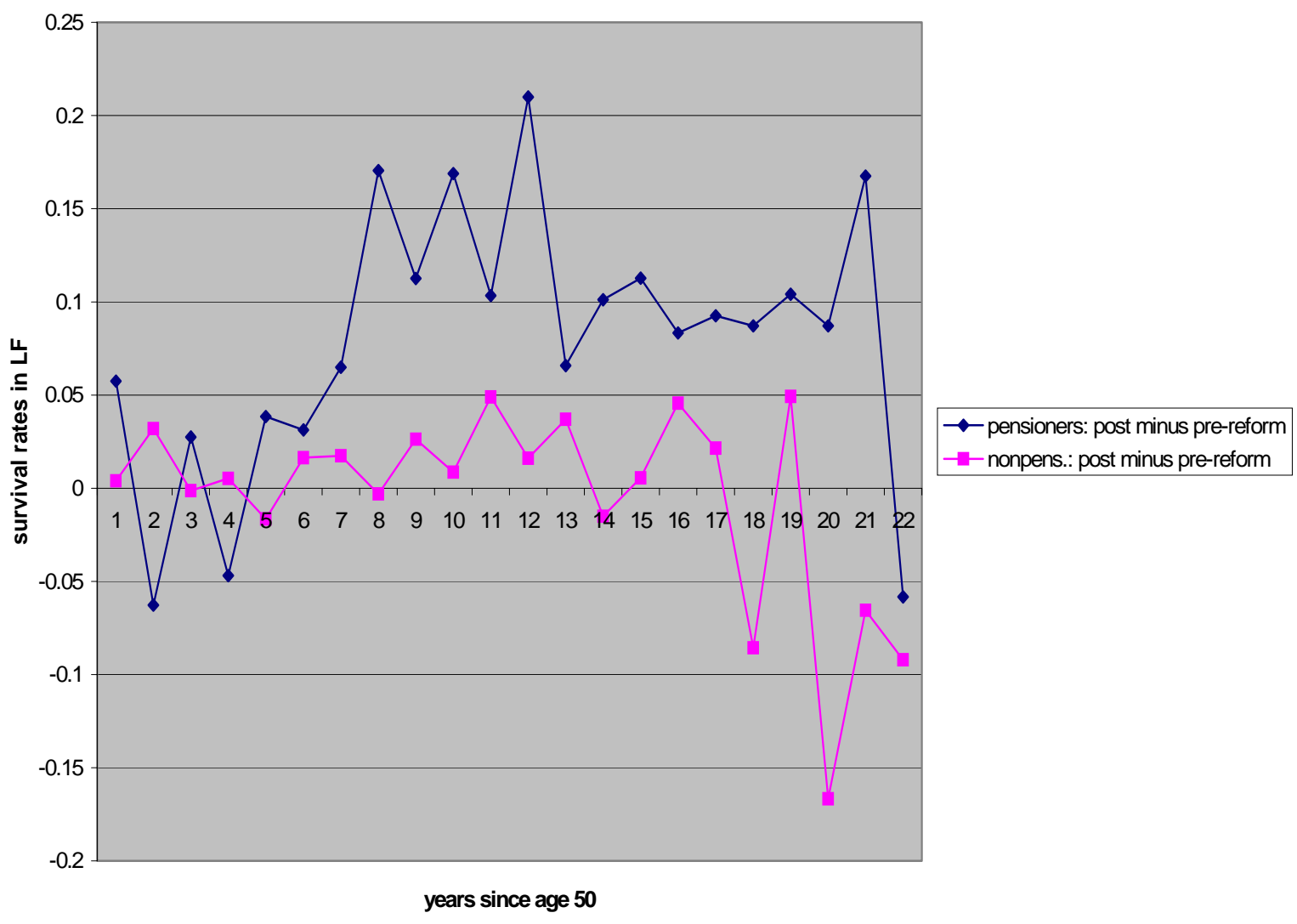


Figure 10: Hazard rates of becoming a pensioner were higher pre-reform

Hazard of becoming a pensioner, pre minus post-reform

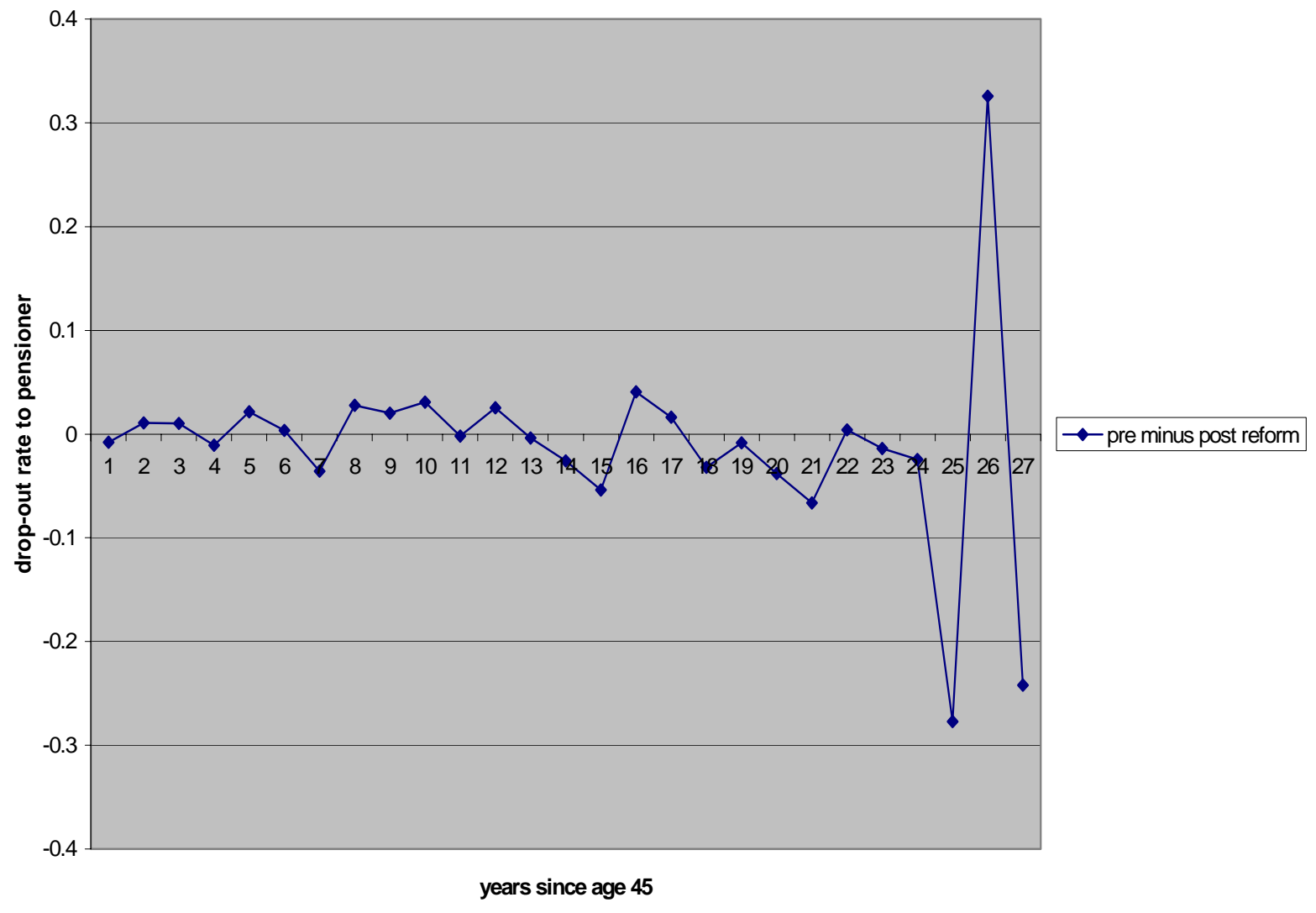


Figure 11: Survival rate as nonpensioner is higher post -reform

Survival rates as nonpensioner, post minus pre-reform

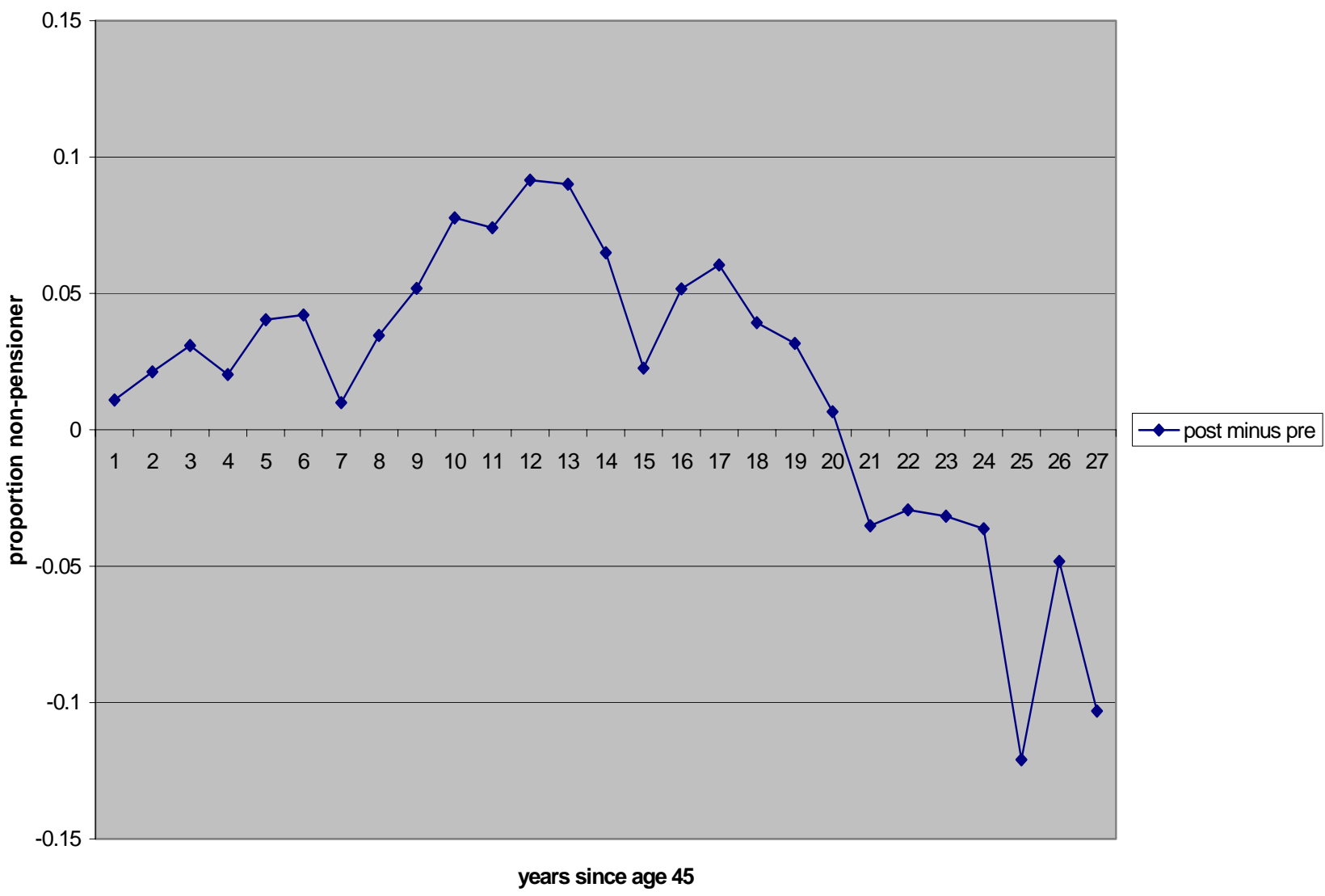




\section{References}

Acuna, Rodrigo and Augusto Iglesias. 2001. "Chile’s Pension Reform After 20 Years”. Social Protection Discussion Paper No. 129. World Bank.

Anderson, Patricia, Alan Gustman and Thomas Steinmeier. 1999. “Trends in Male Labor Force Participation and Retirement: Some Evidence on the Role of Pensions and Social Security in the 1970’s and 1980’s.” Journal of Labor Economics. 17 (4), 757-783.

Arenas, Behrman and Bravo 2004

Baker, Michael and Dwayne Benjamin. 1999. Journal of Labor Economics. 17(4)724-56.

Blau, David. 1994. “Labor force Dynamics of Older Men.” Econometrica. 62(1) 117-56.

Borsch-Supan. Axel. 1998. "Incentive Effects of Social Security on Labor Force Participation: Evidence in Germany and Across Europe.” NBER Working paper 6780.

Borsch-Supan and Reinhold Schnabel. 1999. "Social Security and Retirement in Germany.” In J. Gruber and D. Wise, eds. Social Security and Retirement Around the World. Chicago: University of Chicago Press.

Burtless, Gary. 1986. "Social Security, Unanticipated Benefit increases, and the Timing of Retirement.” Review of Economic Studies. LIII. Pp. 781-805.

Burtless, Gary and Robert Moffitt. 1986. "Social Security, Earnings Tests, and Age at Retirement.” Public Finance Quarterly. 1986. 14 (1): pp. 3-27.

Butler, Monika, Olivia Huguenin and Federica Teppa. 2004. "What Triggers Early Retirement? Results from Swiss Pension Funds”. Working paper. Univ. of Lausanne.

Cheyre, Hernan. 1991. "La Prevision en Chile Ayer y Hoy.” Centro de Estudios Publicos. Santiago.

Coile, Courtney. 2003. "Retirement Incentives and Couples' Retirement Decisions." NBER Working Paper 9496, Cambridge, Mass.: NBER.

Edwards, Sebastian and Alejandra C. Edwards (2002) "Social Security Privatization Reform and Labor Markets: The Case of Chile,” Economic Development and Cultural Change 50 \#3 pp.465-89.

Gruber, Jonathan and David A. Wise eds. 1999. Social Security and Retirement Around the World. Chicago: University of Chicago Press.

Gruber, Jonathan and David A. Wise eds. 2004. Social Security Programs and Retirement Around the World: Micro-Estimation. Chicago: University of Chicago Press. 
Gruber, Jonathan (1997): “The Incidence of Payroll Taxation: Evidence from Chile,” Journal of Labor Economics 15 ( Part 2): S72-S101.

Gustman, Alan and Thomas Steinmeier. 1985. "The 1983 Social Security Reforms and Labor Supply Adjustments of Older Individuals in the Long run.” 3 (2); 237-252.

Hurd, Michael. 1990. "Research on the Elderly: Economic Status, Retirement, and Consumption and Saving.” Journal of Economic Literature. 28 (2). 565-637.

James, Estelle, Alejandra C. Edwards and Rebeca Wong (2003) The Gender Impact of Pension Reform,” Journal of Pension Economics and Finance, July 2003.

James, Estelle, Guillermo Martinez and Augusto Iglesias 2004a. “The Payout Stage in Chile: Who Annuitizes and Why?” working paper.

James, Estelle, Guillermo Martinez and Augusto Iglesias 2004b. "Postponed vs. Early Access to Individual Accounts and its Fiscal Implications in Chile.” Working paper.

Krueger, alan and Jorn-Steffan Pischke. 1999. "The Effect of Social Security on Labor Supply: A Cohort Analysis of the Notch Generation”. Journal of Labor Economics 10 (4): 412-37.

Palacios, Robert and Edward Whitehouse. 1998. "The Role of Choice in the Transition to a Funded System.” Social Protection Discussion Paper No. 9812. World Bank.

Peracchi, Franco and Finis Welch. 1994. "Trends in Labor Force transitions of Older Men and Women.” Journal of Labor Economics, 12 (2), 210-42.

SAFP. (Superintendencia de Administradoras de Fondos de Pensiones). 2003. The Chilean Pension System. Santiago, Chile. 


\section{Endnotes}

${ }^{i}$ For preliminary descriptive statistics see Edwards and Edwards (2002). Gruber (1997) studied the incidence of the payroll tax in Chile.

ii By 1979 the old system was composed of 32 pension funds with more than 100 different programs. It is difficult to obtain precise information about all these subsystems. These descriptions are based on SAFP 2003, Cheyre 1991 and personal communications with Augusto Iglesias, Primamerica. Under the largest sub-system, Servicio Seguro Social (SSS) which covered two-thirds of total contributors (mainly blue collar), workers were eligible for defined benefits after 10 years of contributions and the normal retirement age was 65 for men and 55 for women. However, earlier retirement was possible for those with more than 800 weeks of contributions and for the disabled (which was liberally defined). In the largest public sector sub-system, Empart, retirement age was 65 both for men and women, but those with 25 years of service could retire at 60 . Other sub-systems (e.g. for the banking industry) had still earlier retirement ages. Retirement ages were generally younger prior to parametric reforms in the late 1970's. Lax record-keeping further facilitated early retirement. Although the population in Chile was relatively young, early retirement and evasion resulted in a contributor/pensioner ratio of 2.2 in 1980, lower than in the US today. Despite the high payroll tax, the system was insolvent and $40 \%$ of its costs were covered by subsidies from general revenues.

iii In the new system, $10 \%$ of wages go into the individual accounts $+2.5-3 \%$ are paid for administrative costs and disability and survivors insurance. The 2.5-3\% add-on varied slightly across pension funds (AFP's) and has fallen over time. In 2002 it was 2.4\%, on average (SAFP 2003). While employers paid most of the tax in the old system, workers paid the entire tax in the new system, an increase from $7.25 \%$ to almost $13 \%$ of wages. In the short run, wages were commensurately increased for workers who switched. We don't know how wages adjusted in the long run.

iv Taking account of the $2.5-3 \%$ of wages that were paid for fees, which did not go into the accounts, the rate of return on gross contributions including fees was 7-8\% annually for workers who retired during this period.

$v$ The transition deficit, due to benefits received by workers who did not switch and redemptions of recognition bonds by those who did switch, was covered by the government out of general revenues. This financing gap was substantial-averaging $3.25 \%$ of GDP per year during the first 20 years of the system. However, the incremental cost was much lower, as the government was already paying close to $3 \%$ of GDP to cover the large deficits of the old system (SAFP 2003).

${ }^{v i}$ Almost all pensions drawn in the new scheme during the early and mid-1980's were for disability and survivors' benefits.

vii Chile offers a minimum pension guarantee (MPG)--about 25\% of the average wage--to every worker who has contributed for at least 20 years. If a workers' own pension falls below the MPG, the government subsidizes the pension to bring it up to that level, providing the individual does not have additional income sources. The subsidy may take 
the form of a top-up to an annuity, or payment of a full pension at the MPG level if the individual's account has been depleted through gradual withdrawals.

viii For example, a worker who enters the labor force at age 21 and contributes $10 \%$ net of fees to his account, facing the average wage growth in Chile of $2 \%$ annually and earning $5 \%$ on his investments, will pass the $50 \%$ replacement rate point at age 59 (assuming an expected age of death of 81). This might be considered a "typical" long run case. But if he earns $10 \%$ on his account, as occurred during the first twenty years of the new system, he will pass the $50 \%$ point after 21 years or work, at age 42 . The replacement rate requirement was just raised to $70 \%$ to prevent this outflow from the labor force as many workers are now passing the 21-year point. It will take another 5-10 years before workers reach the $70 \%$ point.

ix Investment options are tightly constrained inside the system, and were even more constrained in the 1980's and 1990's than they are now. Until 2002 individuals had a choice of investment manager but virtually no choice of investment strategy. Since 2002 greater choice of investment options has been allowed but this is still limited to 4 or 5 portfolios. Workers who wish to put all their money into stocks, for example, are not allowed to do so in the system. Payout options are also tightly constrained. Payouts must take the form of annuities or gradual withdrawals according to a formula set by the regulator. Thus, if an individual wishes to be able to cover emergency or other lumpy needs, he must keep some money outside the system. This particularly applies to creditconstrained individuals, who cannot borrow against their social security wealth.

${ }^{x}$ On the one hand, early retirement rules were tighter in the new system than the old. On the other hand, early access was facilitated by the high rate of return to retirement accounts during the 1980's and 1990's, by regulations that allowed the bono to be used for meeting the threshold, and by aggressive marketing of annuities by insurance companies at the earliest age of eligibility. The majority of the current stock of pensioners in the new system are early pensioners but, as we shall show, not as early as in the old system and many of them continue to work (for further discussion see James, Martinez and Iglesias 2004a and b).

xi Alternatively, pensioners may hold their net wage constant while accepting a lower gross wage from their employers, who are therefore more willing to continue employing them even if productivity falls due to aging.

xii Longitudinal data sets have not been available in Chile. However, a new data set has just come on line that gives more detailed retrospective data on earnings and will be linked to AFP data on contributions and pensions. We plan to analyze these data in the future.

xiii Given age-related disability rates, some of our pensioners will undoubtedly be disability pensioners. Most recipients of survivors' benefits and social assistance benefits are women. Most pensioners will not become eligible for the MPG until they are well past age 70. Until that point they will be using up the money in their own accounts or living on an annuity which is more than the MPG. But they may be close to the MPG, which may influence their behavior. 
${ }^{\text {xiv }}$ About $70 \%$ of the labor force contributes at any point in time. The number of affiliates exceeds the number of workers in the labor force but a third of all affiliates are not current contributors. (Arenas, Behrman and Bravo 2004). These may be women who have dropped out of the labor market, the self-employed who are not required to join the system, informal sector workers or pensioners. Since they contribute only sporadically, even if they have pensions at the end these pensions will be small.

xv The increased participation rates over age 65 in the 1990's, despite the fact that most pensioners in this age range retired under old system rules, may be due to the fact that they could re-enter the labor market (or even stay in their previous jobs) as an affiliate of the new system, receiving the defined benefit from the old system plus the account from the new system-which they could not have done before the reform. In this way the reform could affect behavior among the very old and among old system retirees.

${ }^{\text {xvi }}$ After age 65 pension probabilities become slightly higher post-reform due to higher coverage rates, on average, during the post-reform period

xvii Upon retirement, married men are required to purchase joint pensions that provide $60 \%$ of the primary benefit to surviving widows. This reduces their own pension by an actuarially fair amount, depending on the age of their spouse. Additionally, all contributing workers must pay for disability and survivors insurance. Everyone pays the same percentage, about .7\%, of their wage, for this insurance. Older workers, who have a higher probability of disability, and married men, whose wives get survivors benefits, receive an expected value that exceeds their premium, while younger workers, singles and women, who have no qualifying "survivors”, lose.

xviii The Hodrick-Prescott filter or H-P filter is an algorithm for choosing smoothed values for a time series. It produces a smoothed non-linear representation of a time series, one that is more sensitive to long-term than to short-term fluctuations. Following is the $\mathrm{H}-\mathrm{P}$ filter compared with ln(real GDP growth) for Chile, 1960-2002.

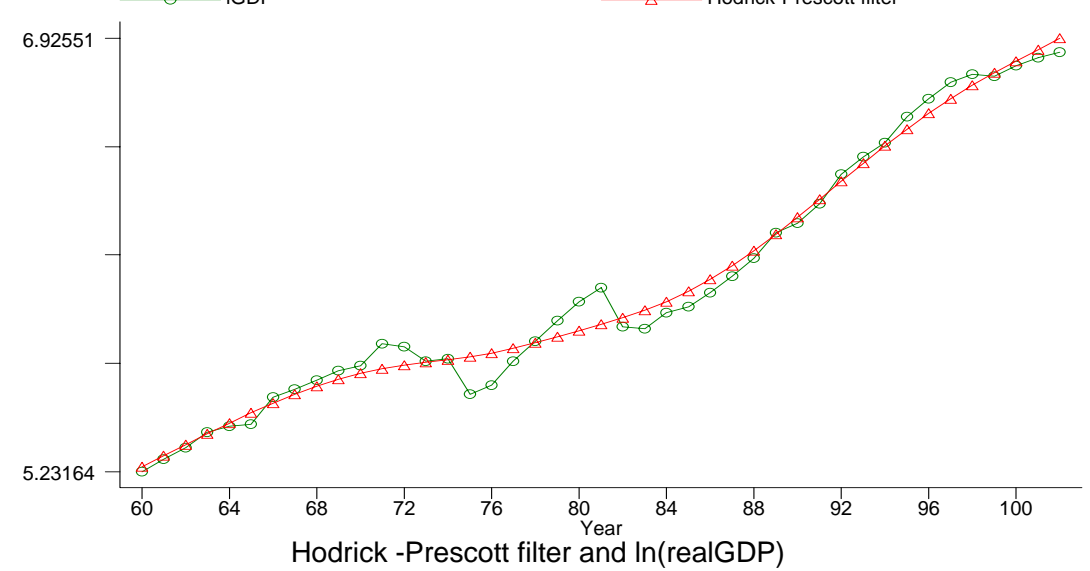

${ }^{x i x}$ But pension size did not increase as rapidly as wages, so if workers reacted to a target wage replacement rate rather than absolute pension size this might have led them to continue working after starting their pensions. It is also possible that the increase in 
lifetime wages would have enabled workers to save more and therefore afford to retire earlier, even though their pensions did not rise as fast as wages. The median pension in our sample rose $25 \%$, the mean pension rose $22 \%$, and the average wage index for the economy rose 35\% between 1981 and 2002. In contrast, real pension values were more volatile but roughly unchanged in value between 1960-61 and 1980-81. Good data on real wages are not available prior to the 1980's.

xx Unemployment in Chile was 8\% in 1960, fell to 3\% by 1973 and then rose to 23\% by 1982 and $15 \%$ in 1986. Over the period 1960-1986 the correlation between time and unemployment was .74. During the post-reform period 1987-2002, unemployment went through an entire cycle, falling to $6 \%$ by 1995 and then rising to $14 \%$ by 2002 . The correlation over this period was only $31 \%$. It is possible that the high positive correlation pre-reform led to an overstatement of negative pre-reform time trends, which in turn would have overstated the reversal in time trend that occurred post-reform.. Use of cohort trends as reform indicators helps to avoid this problem.
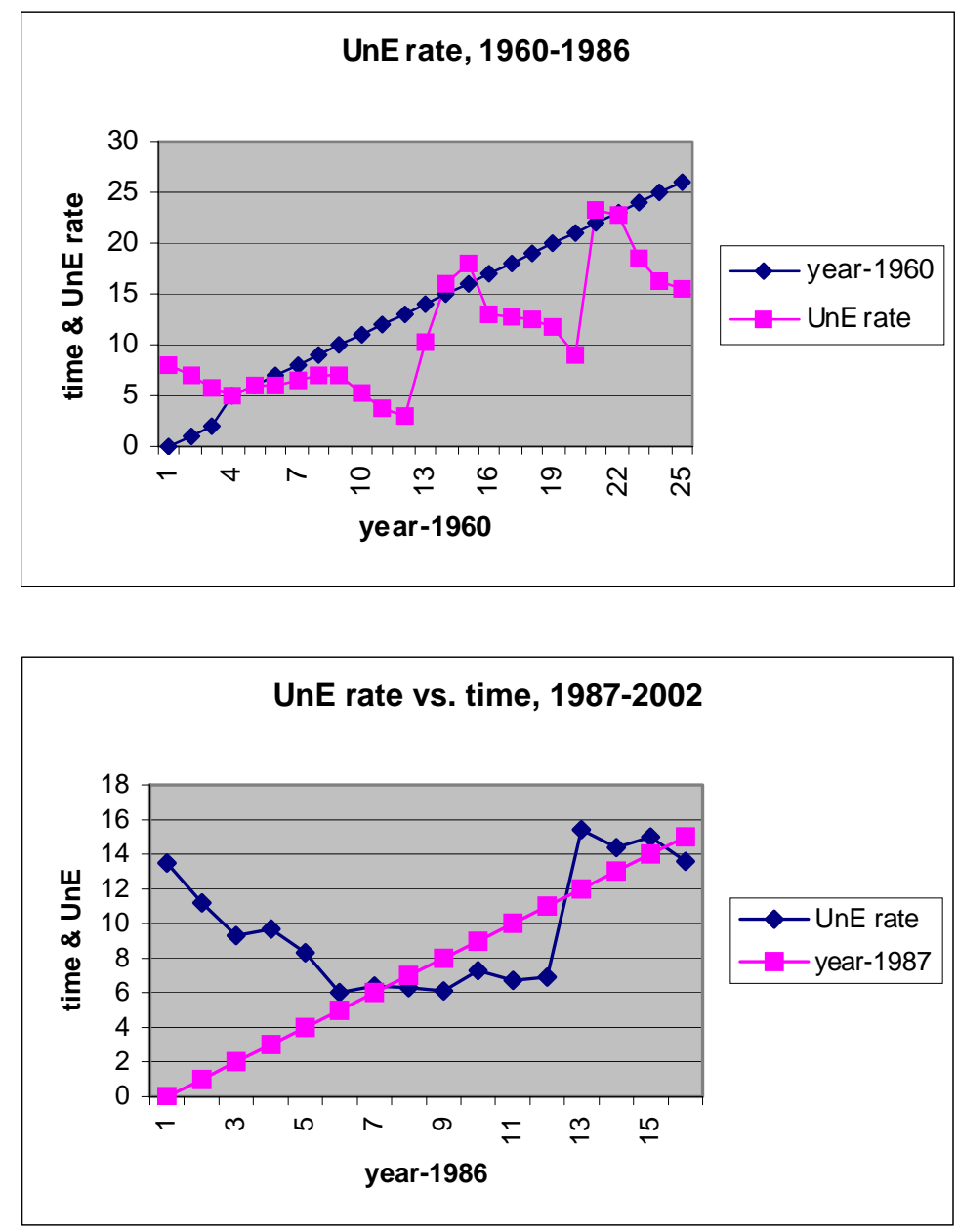

xxi Coh31*d50 refers to everyone who was born in 1931 or after and is observed at age 50 or after. By definition, all these observations took place after the new system was adopted and all these people reached age 50 under the new system, hence could reasonably be expected to make their pension and participation decisions in accordance with the new system rules. In contrast, time $87 * \mathrm{~d} 50$ refers to everyone who is observed 
beyond age 50 after 1987 . This includes people in their 70's and 80's who retired many years before under old system rules. Therefore, coh31*d50 contains less measurement error in targeting the group subject to the new system rules. 